This manuscript is a preprint. It has not yet undergone peer-review. Subsequent versions of this manuscript may thus have different content. If accepted, the final version of this manuscript will be available via the 'Peerreviewed Publication DOI' link on the right-hand side of this webpage. Please feel free to contact any of the authors directly or to comment on the manuscript using hypothes.is (https://web.hypothes.is/). We welcome feedback! 


\title{
Structure and kinematics of an extensional growth fold, Hadahid Fault System, Suez Rift, Egypt
}

\author{
Christopher A-L. Jackson ${ }^{1 *}$, Paul S.Whipp ${ }^{1,3}$, Robert L. Gawthorpe ${ }^{2}$, Matthew M. Lewis ${ }^{1}$
}

${ }^{1}$ Basins Research Group (BRG), Department of Earth Science \& Engineering, Imperial College, Prince Consort Road, London, SW7 2BP, UK

${ }^{2}$ Department of Earth Science, Realfagbygget, University of Bergen, Allegate 41, Bergen N5020, Norway

${ }^{3}$ Current address: Statoil ASA, Bergen, Norway

*Corresponding author email: c.jackson@imperial.ac.uk

\section{Abstract}

Normal faulting drives extensional growth folding of the Earth's upper crust during continental extension, yet we know little of how fold geometry relates to the structural segmentation of the underlying fault. We use field data from the Hadahid Fault System, Suez Rift, Egypt to investigate the geometry and kinematics of a large (30 km long, up to $2.5 \mathrm{~km}$ displacement), exceptionally wellexposed normal fault system to test and develop models for extensional growth folding. The Hadahid Fault System comprises eight, up to $5 \mathrm{~km}$ long segments that are defined by unbreached or breached monoclines. These segments are soft-linked, hard-linked, or defined by a more subtle along-strike transition in overall structural style. High overlap:separation (O:S) ratios between its segments suggest the Hadahid Fault System comprises a single, now hard-linked structure at-depth. We demonstrate that a progressive loss of at-surface displacement along strike of the Hadahid Fault System results in surface-breaking faults and breached monoclines being replaced by unbreached monoclines developed above blind faults. However, shorter along-strike length-scale variations in structural style also occur, with unbreached monoclines developed between breached monoclines. The origin of this variability is unclear, but might reflect local variations in host rock material properties that drive short length-scale variations in fault propagation-to-slip ratio, and thus the timing and location of fold breaching. We show that folding is a key expression of the strain that accumulates in areas of continental extension, and argue that tectono-sedimentary models for rift development should capture the related structural complexity.

\section{Introduction}


Stretching of the Earth's upper crust is invariably accommodated by the development of normal faults. Folds can also be locally important, with extensional growth folds (sensu Coleman et al., 2019) developing around the tips of propagating normal faults (Fig. 1) (e.g. Sterns, 1970; Patton, 1984; Withjack et al., 1990; Schlische, 1994; Gawthorpe et al., 1997; Pascoe et al., 1999; Keller and Lynch, 2000; Maurin and Niviere, 2000; Corfield and Sharp, 2000; Sharp et al., 2000; Withjack \& Callaway, 2000; Willsey et al., 2002; Gawthorpe et al., 2003; Jackson et al., 2006; Ford et al., 2007; Cardozo, 2008; Ferrill \& Morris, 2008; El-Wahed et al., 2010; Ferrill et al., 2007; 2012; Wilson et al., 2013; Deckers, 2015; Tavani et al., 2013; 2015; 2018; Conneally et al. 2017). In two-dimensions, extensional growth folds define upward-widening monoclines (Fig. 1A-C) (e.g. Schlische, 1995; Gawthorpe et al., 1997; Janecke et al., 1998; Khalil and McClay, 2002; Willsey et al., 2002). In threedimensions, extensional growth folds are typically characterised by a relatively smooth, along-strike transition from a breached monocline (i.e. a monocline cross-cut by a normal fault such that it is now defined by a footwall anticline-hangingwall syncline pair) to an unbreached monocline (Fig. 1D) (e.g. Gawthorpe et al., 1997; Lewis et al., 2015; Conneally et al., 2017).

It is well known, however, that normal faults, rather than being represented by a single, relatively planar surface, are commonly segmented, being composed of numerous soft- or hard-linked segments that bifurcate during propagation in both dip and strike directions (e.g. Childs et al., 2003; Walsh et al., 2002, 2003; van der Zee and Urai, 2005; Schöpfer et al., 2006, 2007; Long and Imber, 2011; Giba et al., 2012; Jackson and Rotevatn, 2013; Fossen \& Rotevatn, 2016; Freitag et al., 2017; Camanni et al., 2019). Because of this, fault tip lines can be highly irregular, reflecting spatial variations in host rock mechanical properties and related differences in propagation-to-slip ratio, and/or spatially selective reactivation of pre-existing structures (e.g. Baudon and Cartwright, 2008). We may therefore expect that extensional growth folds will reflect the geometric and kinematic complexity of their causal normal faults. These folds should essentially be more complex than predicted by current models, which are largely based on studies of relatively small, geometrically simple fault segments (e.g. Gawthorpe et al., 1997; Sharp et al., 2000; Corfield and Sharp, 2002; Lewis et al., 2015).

Understanding the structure and kinematics of extensional growth folds is important. These structures, which are widespread in some rifts (e.g. Gulf of Suez; Moustafa, 1987; Withjack et al., 1990; Gawthorpe et al., 1997; Sharp et al., 2000; Jackson et al., 2006; El-Wahed et al., 2010; Lewis et al., 2015), and well-developed adjacent to certain faults in others (e.g. offshore western Norway; Pascoe et al., 1999; Corfield and Sharp, 2000; Bell et al., 2014; Whipp et al., 2014), control basin geometry, sediment dispersal, and, ultimately, the syn-rift stratigraphic record of continental extension (see review by Coleman et al., 2019). It is also critical to understand the origin and style of foldrelated extensional strains (so-called "continuous deformation"; Walsh \& Watterson, 1989) when reconstructing the growth of normal faults (see also Childs et al., 2017 and Lăpădat al., 2017). 
(i.e. they can have amplitudes of several tens to hundreds of metres, widths of several kilometres, and strike extents of several tens of kilometres) and three-dimensional complexity. They are therefore much larger than the typical size of many field exposures, which commonly permit only a depthlimited perspective of fold structure and growth, at one specific along-strike location (see Patton et al., 1994 and Sharp et al., 2000 for exceptions). In contrast, high-quality, 3D seismic reflection data permit four-dimensional analysis of large extensional growth folds, although the impact of fault segmentation on fold geometry and kinematics has only very rarely been studied in detail (see Conneally et al., 2019). Here we use high-resolution field mapping (1:2000 and 1:5000 scale) to describe the geometric and kinematic development of the Hadahid Fault System, an exceptionally well-exposed, crustal-scale ( $30 \mathrm{~km}$ long, up to $2.5 \mathrm{~km}$ displacement) fault system located in the ElQaa Fault Block, Suez Rift, Egypt (Figs 2 and 3). Our data allow us to test and develop models for the development of extensional growth folds.

\section{Geological Setting}

\subsection{Regional tectonic and structural framework}

The Neogene Suez Rift developed during Late-Oligocene to Early-Miocene (24-15.5 ma) rifting of the African and Arabian plates (e.g. Garfunkel and Bartov, 1977; Colletta et al., 1988; Lyberis, 1988; Patton et al., 1994; Bosworth and McClay, 2001). The NW-trending Suez Rift is $300 \mathrm{~km}$ long and up to $80 \mathrm{~km}$ wide, representing the northern arm of the failed intra-continental Red Sea rift system (inset in Fig. 2A). The Suez Rift consists of several large, broadly NW-SE-striking, normal fault systems that bound up to $50 \mathrm{~km}$ long and 10-20 km wide half-graben (Fig. 2) (e.g. Bosworth, 1995; Moustafa, 1996; McClay et al., 1998; Bosworth and McClay, 2001).

\subsection{Structural evolution of the El Qaa Fault Block and Hadahid Fault System}

The El Qaa fault block is located on the Sinai margin of the Suez Rift. The fault block is defined by a $40 \mathrm{~km}$ long by $25 \mathrm{~km}$ wide half-graben, which is bound to the east and west by NW-SE to NNWSSE-striking, W-dipping, large displacement (up to $5 \mathrm{~km}$ ) normal faults (e.g. Eastern Boundary and Coastal fault belts, and the Nezzazat, Sinai Massif, and Gebah faults; Figs 2-4) (sensu Sharp et al., 2000; see also Moustafa and El-Raey, 1993; Patton et al., 1994). This study focuses on the Hadahid Fault System, an intra-half-graben fault bounding the south-western margin of the Hadahid Fault Block (Fig. 3) (e.g. Moustafa and El-Raey, 1993). The Feiran Transfer Zone defines the northern limit of the Hadahid Fault System; here, displacement is transferred north-eastwards onto the Baba-Sidri Fault via several broadly NW-striking, SW-dipping, moderate displacement $(<500 \mathrm{~m})$ normal faults (Fig. 2) (e.g. Moustafa, 1992; Moustafa and El-Raey, 1993; Sharp et al., 2000). The Hadahid Fault 
112 System is defined by several unbreached (Figs 3, and 4C, G, H and I) and breached (Figs 3, and 4A, 113 B, D-F) forced folds (e.g. Patton, 1984; Withjack et al., 1990; Gawthorpe et al., 1997; Gupta et al., 114 1999; Sharp et al., 2000; Jackson et al., 2006; Lewis et al., 2015). The detailed structure and evolution

115 of the Hadahid Fault System forms the focus of this study.

\subsection{Stratigraphic Framework}

The Suez Rift is underlain by Precambrian, 'Pan African' crystalline basement. The overlying sedimentary sequence is divided into three megasequences (Fig. 5). Megasequence One is c. $500 \mathrm{~m}$ thick and composed of Cambrian to Lower Cretaceous clastics (Nubian Sandstone). This succession is conformably overlain by Mesozoic, mixed carbonate-clastic, and Early Tertiary, carbonate-dominated rocks, which together comprise Megasequence Two (c. 650 m thick; Patton et al., 1994; Sharp et al., 2000). The competency contrast between mudstone-dominated intervals, such as the Duwi, Esna and Darat formations, and carbonate- and sandstone-dominated units in the upper part of Megasequence Two results in a strongly layered mechanical stratigraphy (Fig. 5); this exerts a strong control on the evolution of syn-rift structural styles, allowing decoupling and promoting extensional forced folding (sensu Coleman et al., 2019; see also Withjack et al., 1990; Sharp et al., 2000; Withjack \& Callaway, 2000; Jackson et al., 2006; Wilson et al., 2009; Lewis et al., 2015). Megasequence Three represents syn- to post-rift deposits associated with formation of the Suez Rift. The lower, Oligo-Miocene, synrift part of Megasequence Three consists of non-marine (Abu Zenima Formation; 24-21.5 ma), tidalto-marginal marine (Nukhul Formation; 21.5-19.7 ma), and open marine (Rudeis Formation; 19.7-15.5 ma) deposits (Gharandal Group) (Fig. 5). The upper, post-rift part of Megasequence Three

134 is composed of clastic, carbonate and evaporite rocks (Ras Malaab Group) (e.g. Patton et al., 1994; Sharp et al., 2000). Due to a lack of hangingwall exposure, the full thickness of Megasequence Three in the El-Qaa fault block is unknown. However, Lewis et al. (2015) demonstrate that Abu Zenima, Nukhul and Rudeis formations are collectively at least $60 \mathrm{~m}$ thick.

\subsection{Timing of deformation on the Hadahid Fault System}

Although syn-rift growth strata are not preserved along its entire length, the following four observations by Lewis et al. (2015) place some constraints on the timing of deformation on the Hadahid Fault System: (i) early syn-rift strata of the Abu Zenima Formation (23.5-21 Ma; Fig. 5) onlap pre-rift strata (Mokattam Formation) along the Hadahid, and East and West Feiran monoclines (Figs $3 \mathrm{~A}$, and $4 \mathrm{G}$ and $\mathrm{I}$ ), suggesting these structures initiated during the initial stages of rifting in the

146 Late Oligocene; (ii) early syn-rift strata of the Abu Zenima Formation (23.5-21 Ma; Fig. 5) are locally 147 preserved in syn-depositional faults dissecting the Hadahid, and East and West Feiran monoclines 148 (not shown in the regional map in Fig. 3), suggesting these faults, which Lewis et al. (2015) infer 
149 were kinematically linked to the forced folds on which they occur, initiated during the initial stages of 150 rifting in the Late Oligocene; (iii) late pre-rift (Eocene) strata of the Thebes Formation are thrust over 151 early syn-rift (23.5-21 Ma) strata along the Ratamat Segment (see below), suggesting fold tightening

152 and deformation of the monocline middle limbs after rift initiation, perhaps during the Early Miocene;

153 and (iv) syn-rift depocentres of the Abura Graben and Gebah Half-Graben, which are located at the 154 southern end of the Hadahid Fault System and that contain syn-rift strata as young as 16.9 Myr (i.e. 155 Abu Zenima, Nukhul, and Rudeis formation; Fig. 5), are cross-cut by the Hadahid Fault System, implying this structure was likely active post-Early Miocene.

\section{Structural style of the Hadahid Fault System}

160 We identify eight fault (i.e. Gebah and Abura, Hadahid Fault, Theghda, Abyad, and Ratamat fault 161 segments), and three fold segments (i.e. Hadahid, and the East and West Feiran monoclines) along the 162 Hadahid Fault System, based on abrupt along-strike changes in fault strike and/or structural style, for example from a breached to an unbreached monocline (Fig. 3B) (cf. Stewart \& Taylor, 1996). For much of its length, the hangingwall of the Hadahid Fault System is not exposed, being buried beneath thick Quaternary deposits of the El-Qaa Plain. In these locations we cannot therefore constrain the location of the master fault responsible for generating the bulk of the observable strain, or the amount of displacement on the fault (Fig. 3A; see also Fig. 4A, B and D). For example, even where we observe a fault of appropriate scale (i.e. several hundreds of metres of throw), strike (e.g. ESE-WNWto-SSE-NNW) and dip (i.e. broadly south-westwards), in broadly the correct structural position (i.e. immediately to the E or NE of the El-Qaa Plain), it remains unclear if this is the Hadahid Fault System 'master fault'. However, we use the following criteria to help constrain the position of the master fault: (i) where reverse faults occur, these likely lie in the hangingwall of the master fault, or on the hangingwall side of the up-dip projection of the master fault in cases where it is blind (cf. Fig. 1); and (ii) growth fold (monocline) breaching typically results in preservation of steeply dipping (or overturned) beds within the fault zone or in the immediate hangingwall of the fault; as a result of this, footwall bedding increases in dip towards the fault, and where bedding dips steeply (i.e. $>70^{\circ}$ ), the master fault is likely at- or near-surface.

Ignoring the fact that the position of the master fault is locally uncertain, the overall northwestward transition from breached to unbreached monoclines clearly defines a north-westward decrease in the ratio between discontinuous (i.e. fault offset-related) and continuous (i.e. fold-related), at-surface deformation (Figs 3 and 4A-I). One hypothesis links this along-strike change in structural style to the north-westwards propagation of the Hadahid Fault System from its branchline with the Gebah and Sinai Massif faults. In this model, extensional growth folds formed and were breached earlier in the SE than they were in the NW. The cessation of extension and the death of the Hadahid 
186 to this along-strike in structural style as being a so-called 'propagation effect'. An alternative 187 hypothesis is that the Hadahid Fault System nucleated broadly synchronously along its length and 188 then propagated upwards, more quickly in the SE, which ultimately leading to north-westwards 189 propagation of the fault system's surface trace. We may refer to this along-strike in structural style as 190 being a so-called 'geometric effect'. Differentiating between these two hypotheses is impossible 191 given: (i) our structural level of inspection is restricted to the Earth's surface, thus we cannot 192 demonstrate that fault-related displacement (i.e. discontinuous deformation) increases north193 westwards at deeper structural levels (e.g. at the depth of top crystalline basement or top pre-rift; Fig.

194 5); and (ii) discontinuous exposures of very poorly dated syn-rift deposits in the hangingwall of the 195 Hadahid Fault System means we cannot establish the relative timing of faulting and folding along the 196 structure; i.e. do the very earliest syn-rift growth strata become younger towards and thus document 197 the north-westward initiation of folding and subsequent faulting, and hence north-westwards 198 propagation of the fault system?

199 In this section we describe and interpret the structural style (i.e. plan-view and cross-sectional 200 geometry) of the eight fault-fold segments of the Hadahid Fault System from south to north, following 201 the inferred direction of displacement decrease along the structure. Where we infer the displacement of the master fault, it should be noted these values are based on stratigraphic cut-offs and do not include the ductile component of deformation (e.g. folding); displacement values are, therefore, minimum estimates of extensional strain (e.g. Walsh \& Watterson, 1991).

\subsection{Gebah Segment}

207

208 The Gebah Segment is located at the southern end of the Hadahid Fault System and is defined by NNW-SSE- to WNW-ESE-striking, W-SW to W-dipping, c. $3.5 \mathrm{~km}$ long normal fault (Figs 3B, 6A and B). This segment splays off the Eastern Boundary Fault Belt, at the branchpoint between the

211 Gebah and Sinai Massif segments (Figs 3B, 6A and 7). Along much of its length the immediate

212 footwall of the Gebah Segment is defined by a c. $500 \mathrm{~m}$ wide anticline that is deformed by numerous 213 normal faults (Figs 6A and 7). NE of this anticline, a 1-1.5 km wide, N-trending, syn-rift half-graben 214 is developed, which is bound on its eastern margin by the Eastern Boundary Fault Belt (Gebah Half215 Graben; Figs 5A, 6 and 7; Lewis et al., 2015).

216 Based on: (i) the sharp increase in topographic relief along the north-eastern margin of the El217 Qaa Plain at its contact with exposed pre- and syn-rift rocks; and (ii) the presence of faulted and 218 folded syn-rift strata in the Gebah Half-Graben, we infer that the master fault of the Hadahid Fault 219 System is surface-breaching along the Gebah Segment. As such, we interpret that the anticline 220 characters of the footwall of the Gebah Segment represents the footwall portion of a breached 221 monocline; the related hangingwall syncline is buried beneath the El-Qaa Plain (cf. Fig. 1). Because 
of this, we cannot constrain the displacement along this part of the Hadahid Fault System (Fig. 6A and B).

\subsection{Abura Segment}

The Abura Segment is defined by a WNW-ESE-striking, SW-dipping, c. $2 \mathrm{~km}$ long normal fault (Fig. 6A and C). The structural style of the Abura segment is similar to that of the Gebah Segment, with syn-rift strata in its footwall defining a faulted footwall anticline. Because of this structural similarity, we also interpret that the Abura Segment defines a breached monocline, with the hangingwall syncline buried beneath the El-Qaa Plain. (Fig. 6A and B). Again, because of this, we cannot constrain the displacement along this part of the Hadahid Fault System (Fig. 6A and C).

\subsection{Theghda Segment}

The Theghda Segment is c. 4.5 long, trends WNW-to-NW, and is defined by strata that dip SSW (along its southern part) or WSW (northern part), and which define a c. $1.5 \mathrm{~km}$-wide anticline (Figs 8A and 9). Dominantly WSW-ESE-to-NW-SE-striking, SSW-to-SW-dipping, moderate-throw (up to $100 \mathrm{~m}$ ) normal faults are locally developed along the Theghda Segment.

Based on outcrop relationships and exposure levels, there are three possible interpretations for the location of the Hadahid Fault System master fault along the Theghda Segment. First, the master fault may be represented by the normal faults mapped to the NNE of the monocline middle limb. In this interpretation, Eocene strata exposed along the southern part of the segment lie in the faults hangingwall, and are eroded and thus absent further NW, whereas Cretaceous strata along the northern part of the segment lie in its footwall (Fig. 8B). Second, the master fault could be blind, underlying the monocline middle limb (i.e. the interpretation shown in Figs $4 \mathrm{C}$ and 8B). Finally, the master fault could lie SSW of the main outcrop belt, beneath the El-Qaa Plain; in this interpretation, Eocene and Cretaceous strata lie in the faults footwall, with Eocene strata absent along northern part of the segment due to erosion (interpretation not shown). In all three interpretations the eastern part of the master fault would lie directly along strike of where we map it along the Abura Segment (Fig. 8A). Given that stratal dips increase towards and are at a maximum immediately adjacent to the ElQaa Plain (Fig. 8B), we reject the first interpretation, as this would require a progressive decrease in stratal dips SSW of the faults juxtaposing Eocene and Cretaceous strata (Fig. 8). We therefore favour the second or third interpretation; the former suggests an along-strike decrease in displacement on the fault, such that its tips plunges towards and is blind in the WNW, whereas the latter envisages the fault is surface-breaking (but just not observable). 
260 The Abyad Segment has a similar overall structural style and is of similar scale to that of the adjacent

261 Theghda Segment, being c. $4 \mathrm{~km}$ long and trending NW, and characterised by SW-dipping strata that

262 define an up to c. $1 \mathrm{~km}$-wide anticline (Fig. 10). Numerous NW-SE-striking, predominantly SW-

263 dipping, low-throw (up to $50 \mathrm{~m}$ ) normal faults are present along the Abyad Segment, defining an up to

264 c. $500 \mathrm{~m}$-wide zone of intense deformation. These faults bound rotated blocks of the Matulla

265 Formation, within which mudstones layers are highly attenuated (Fig. 11A). 5-30 m wide, faultbounded blocks of intensely fractured Sudr Chalk occur within the fault zone (Fig. 14).

We again suggest there are three possible interpretations for the position of the master fault in this location. For reasons outlined above, we again favour an interpretation that: (i) the master fault is blind, underlying the monocline middle limb (i.e. the interpretation shown in Fig. 10B); in this interpretation, the zone of relatively low-throw normal faults could represent the upper tip of the master fault, which in this case would lie just below the level of exposure (cf. Fig. 1B); or (ii) the master fault is surface-breaking, but lies SSW of the main outcrop belt, beneath the El-Qaa Plain.

\subsection{Ratamat Segment}

The c. $3 \mathrm{~km}$ long, NNW-to-N-trending Ratamat Segment displays a broadly similar geometry to the Abyad and Theghda segments, being defined by SW-to-W-dipping strata that define a c. $1 \mathrm{~km}$-wide anticline that is deformed by low-throw normal faults towards its southern end (Fig. 12A and B). These faults bound blocks of the Matulla Formation, within which mudstone layers are highly attenuated (Fig. 13A). Heavily fractured blocks of Sudr Chalk are also present between closely spaced faults. The Ratamat Segment differs to the Abyad and Theghda segments in that reverse faults are well-developed along its central and northern parts. Along its central part, a NNW-SSE-striking thrust places steep to locally-overturned Thebes Formation carbonates on top of overturned, mixed carbonate-clastics of the Darat and Mokattam formations (Figs 12A and B, and 13B). Further north, two E-dipping, N-S-striking, c. $1 \mathrm{~km}$ long thrusts occur, placing overturned pre-rift strata onto steepdipping to overturned syn-rift strata (Figs 12A and C, and 13C).

Observations from numerical and physical models (Fig. 1A and B), and from other natural examples of extensional growth folds (e.g. Sharp et al., 2000; Jackson et al., 2006; Coleman et al., 2019) (see also Fig. 1C), suggest that the reverse faults lie in the immediate hangingwall of the master fault. As such, we interpret that the Hadahid Fault System master fault lies east of these reverse faults (interpretation shown in Fig. 12). Locally, however, the master fault may be blind, as suggested by the intact monocline defining the middle of the Ratamat Segment. Even here, reverse faults locally offset the monocline limb, suggesting the upper tip of the master fault is near-surface (interpretation shown in. Fig. 12B; see also Fig. 1A). 
298 The Hadahid Monocline is a $5 \mathrm{~km}$ long, NW-SE striking, SW-facing, unbreached monocline, the 299 middle limb of which increase in dip from NW to SE (from $40^{\circ}$ to locally overturned) (Fig. 14).

300 Overall, the dip of the monoclines middle limb $\left(<65^{\circ}\right)$ immediately adjacent to the El-Qaa Plain is less

301 than that observed on segments to the SE. In the SE, where the monocline middle limb dips more steeply $\left(>65^{\circ}\right)$, several NW-SE-striking, moderately $\left(30-50^{\circ}\right)$ NE-dipping reverse faults place steeplydipping-to-locally overturned pre-rift strata on overturned syn-rift strata (Fig. 14A and B). These structures are geometrically similar to those observed along the Ratamat Segment, suggesting that, like the central part of that structure, the upper tip of the master fault is near-surface and is, at its southern end at least, represented by the zone of at-surface, relatively low-throw normal faults described above. Immediately to the NW of the zone of reverse faults, where it dips more gently, the monocline middle limb is undeformed; further to the NW, where it passes into the Hadahid Fault Segment, normal faults become more common (see below) (Fig. 14A and C). Along the entire length of the Hadahid Monocline, syn-rift sandstones onlap pre-rift carbonates across a low-angle, angular unconformity (c. $10^{\circ}$ angular discordance) (Figs 14A and C, 15 and 17) (see Lewis et al., 2015).

\subsection{Hadahid Fault Segment}

The Hadahid Fault Segment is c. $5.5 \mathrm{~km}$ long, strikes N-S, and is defined by a breached, W-facing monocline (Figs 16 and 17) that is deformed by several N-S-to-NW-SE-striking, steeply $\left(70-80^{\circ}\right)$ and broadly W-dipping, $0.5-2 \mathrm{~km}$ long normal faults that have a maximum throw of c. $300 \mathrm{~m}$ (Figs 16 and 17). The Hadahid Fault Segment is one of the few places where the hangingwall of the Hadahid Fault System is relatively well exposed; here we see relatively steeply $\left(c .60^{\circ}\right) \mathrm{W}$-dipping strata at the segment centre, with these pre-rift strata onlapped by syn-rift strata across a low-angle $\left(c .10^{\circ}\right.$ angular discordance) unconformity (Figs 16 and 17). We infer the Hadahid Fault Segment is represented by the faults that breach the related monocline east of the position where syn-rift strata onlap it. Accordingly, we interpret this monocline is a breached extensional growth fold (Figs 16 and 17; cf. Fig. 1A and C).

\subsection{Feiran Monoclines}

The Feiran Monoclines are represented by two NW-SE striking, SW-facing, up to $4.5 \mathrm{~km}$ monoclines that overlap by $c .1 .75 \mathrm{~km}$ and are separated across-strike by $1-5 \mathrm{~km}$ (the West Feiran and East Feiran monoclines; Figs 2, 3, 18 and 19). The West Feiran monocline plunges north-westwards and is breached at its southern end by a steeply $\left(c .70^{\circ}\right) \mathrm{SW}$-dipping fault that tips out just north of Wadi 
333 Feiran monocline also plunges to the NW, with stratal dips on the middle limb decreasing along-strike 334 from $c .35^{\circ}$ to $c .10^{\circ} \mathrm{WSW}$ (Fig. 18A). Variably striking, relatively small (up to $1.2 \mathrm{~km}$ long and with 335 up to $60 \mathrm{~m}$ displacement) normal faults deform the monocline middle limb (Fig. 18A). Pre-rift rocks

336 defining the East and West Feiran monoclines are onlapped by syn-rift deposits across an angular 337 unconformity defined by a 5-10 dip discordance (Figs 18 and 19) (see Lewis et al., 2015).

338

339

\section{Discussion}

340

341 Current geometrical models for extensional growth folds predict a relatively smooth, along-strike 342 transition from a breached monocline to an unbreached monocline, the latter being developed above 343 the smoothly plunging, upper tip-line of the underlying (and laterally related) normal fault (e.g. 344 Gawthorpe et al., 1997; Gawthorpe \& Leeder, 2000; Cardozo, 2008; Coleman et al., 2019). The 345 Hadahid Fault System displays many of the geometrical characteristics captured in this model. For 346 example, the inferred north-westward decrease in bulk displacement on the fault system is associated 347 with an overall change in structural style, from breached monoclines in the SE (e.g. Gebah Segment) 348 to unbreached monoclines in the NW (e.g. Feiran monoclines). However, we show that, in detail, the 349 along-strike transition in structural style is more discontinuous, with unbreached monoclines (i.e. 350 Hadahid Monocline) being flanked by breached or unbreached monoclines (i.e. Ratamat and Hadahid 351 segments) (Figs 3 and 14). Individual segments of the Hadahid Fault System are also flanked (and 352 defined) by segment boundaries that are; (i) unbreached at the structural level of exposure (e.g. 353 between the West and East Feiran monoclines; Figs 3 and 18); (ii) breached and defined by a 354 pronounced bend in the fault-fold trace (e.g. between the Hadahid Monocline and Ratamat segments; 355 Figs 3 and 14; and between the Ratamat and Abyad segment; Figs 3 and 12); or (iii) are defined by a 356 more subtle transition in overall structural style (e.g. between the Theghda and Abyad segments; Figs 3573 and 10). Unbreached segment boundaries are characterised by relatively small (c. $2 \mathrm{~km})$ across358 strike separations and large (c. $3 \mathrm{~km}$ ) along-strike overlaps; these segments are thus defined by high 359 overlap:seperation (O:S) ratios (sensu Whipp et al., 2017) (Figs 3 and 18). In the case of breached 360 segment boundaries, the strike-normal step in the faults plan-view trace is similarly small (i.e. 361 maximum $500 \mathrm{~m}$ ) relative to the length of the bounding segments (typically at least $4 \mathrm{~km}$ ) (Figs 3, 10 362 and 12). We tentatively suggest that the high O:S ratios between unlinked segments of the Hadahid 363 Fault System, as well as the narrow width of breached relays, together suggest the structure is defined 364 by a single, hard-linked structure at-depth, which splays upwards into and is thus defined by, several segments at shallower depths (Fig. 20). Similar geometries are observed in 3D seismic reflection data from the Taranaki Basin, offshore New Zealand, where Conneally et al. (2017) describe segmented fault-fold systems, separated by relays at relatively shallow structural depths, above and related to upward progradation of a single, c. $8 \mathrm{~km}$-long. basement-involved normal fault, (i.e. their fig. 8). 
Where data quality and quantity permit three-dimensional mapping of extensional growth folds and causal faults (e.g. Corfield and Sharp, 2000; Ford et al., 2007), the relatively short lengthscale $(<5 \mathrm{~km})$ variations in structural style we described from the central part of the Hadahid Fault System are absent. The reason for this is unclear, and may reflect the fact that the Hadahid Fault System was associated with non-uniform upward propagation of its upper tip, superimposed on the overall north-westwards propagation of the fault. Non-uniform propagation could be controlled by short length-scale variations in the mechanical properties of the faulted host rock and associated changes in the propagation-to-slip ratio (Hardy and McClay, 1999; Finch et al., 2004; Hardy and Finch, 2006). A consequence of this would be that, above portions of the fault tip that were propagating relatively rapidly, monoclines would be breached, with intact monoclines being preserved along-strike in locations where, at least locally, tip propagation was relatively slow. Such variability may therefore be absent in subsurface examples due to: (i) seismic data resolution being insufficient to resolve relatively low-displacement structures that locally breach seemingly unbreached monoclines (e.g. Lewis et al., 2013); and/or (ii) because the faulted and folded host rock is relatively lithologically and thus mechanically homogeneous. For example, in the Taranaki Basin example of Conneally et al. (2017), the fault grew in a relatively homogenous, mudstone-dominated succession. Irrespective of what controls the short length-scale structural variability seen along the Hadahid Fault System, our study supports the notion that including the ductile component of deformation (i.e. folding) is key when defining the geometry and assessing the kinematics of segmented normal fault systems (e.g. Walsh \& Watterson, 1991).

Where unbreached monoclines are preserved, or where the steep-dipping limbs of breached monoclines are exposed in the fault system hangingwall, most commonly towards the centre of the Hadahid Fault System, reverse faults are relatively well-developed. It is likely these structures are not developed to the NW due to the lower total bulk strains (i.e. faulting and folding); to the SE, these structures may be developed, but are simply not exposed, being buried beneath hangingwall strata due to higher strains and, therefore, larger discrete, fault-related displacements. Thrusts are rarely described from seismic reflection datasets, but are common in exposed forced folds in the Suez Rift (Withjack et al., 1990; Gawthorpe et al., 1997; Sharp et al., 2000; Jackson et al., 2006). The apparent lack of thrusts in seismic reflection datasets may simply reflect the fact that many thrusts have low displacements $(<100 \mathrm{~m})$, are steeply dipping $\left(>50^{\circ}\right)$, and are thus unlikely to be imaged in seismic reflection datasets (although see Fig. 1C for an exception).

\section{Conclusions}

We used field data from the Hadahid Fault System, Suez Rift, Egypt to investigate the geometry and

404 kinematic development of an exceptionally well-exposed normal fault system. We showed that this 30

$405 \mathrm{~km}$ long fault system, which has up to $2.5 \mathrm{~km}$ of displacement, comprises eight, up to $5 \mathrm{~km}$ long 
segments that are defined by unbreached or breached, hard- or soft-linked monoclines. The high overlap:seperation (O:S) ratios between the constituent segments of the Hadahid Fault System suggest it passes upwards from a single, through-going structure at-depth, into a more strongly segmented feature at shallower depths. We infer that the along-strike transition from breached to unbreached monoclines records a progressive loss of displacement along the Hadahid Fault System at deeper structural levels and may suggest that the surface trace of the fault propagated north-westwards. We document short $(<4 \mathrm{~km})$ length-scale variations from unbreached to breached monoclines, which may reflect variations in the fault propagation-to-slip ratio, and the timing and location of growth fold breaching, perhaps linked to local variations in host rock material properties. We conclude that growth folding is a key expression of continental rift-related strain, and that tectono-sedimentary models for rift basin development must incorporate related structures.

\section{Acknowledgements}

Financial support for this study was provided by an Engineering and Physical Sciences Research Council (EPSRC) bursary and Statoil ASA (now Equinor ASA) via a Natural Environmental Research Council (NERC) facilitated CASE Funding. Additional support was provided by the Central London Research Fund, an Elspeth Matthews Grant from the Geological Society of London, and an award from the AAPG Grants-in-Aid scheme. The authors extend their thanks to Paul Wilson, Ian Sharp and Nestor Cardozo for insightful discussions in the field. Adel Moustafa is acknowledged for his regional structural mapping in the Suez Rift, which provided an excellent starting point for this work. Wind Sand Stars, UK and Abanoub Travel, Egypt are thanked for their logistical support throughout the fieldwork programme.

\section{References}

Allmendinger, R.W., 1998. Inverse and forward numerical modeling of trishear fault-propagation folds. Tectonics, 17, 640-656.

Baudon, C. \& Cartwright, J., 2008. The kinematics of reactivation of normal faults using high resolution throw mapping. Journal of Structural Geology, 30, 1072-1084.

Bell, R.E., Jackson, C.A.L., Whipp, P.S. and Clements, B., 2014. Strain migration during multiphase extension: Observations from the northern North Sea. Tectonics, 33, 1936-1963. dating of the early to middle Miocene within the Suez rift. AAPG Bulletin, 79, 1197-1198. 
444 Bosworth, W., 1995. A high-strain rift model for the southern Gulf of Suez (Egypt). Geological Society, London, Special Publications, 80, 75-102.

Bosworth, W., McClay, K., 2001. Structural and stratigraphic evolution of the Gulf of Suez rift, Egypt: A synthesis. In: Ziegler, P.A., Cavazza, W., Robertson, A.H.F., Crasquin-Soleau, S., (Eds.), Peri-Tethys Memoir 6: Peri-Tethyan Rift/Wrench Basins and Passive Margins, Mémoirs du Muséum National d'Historie Naturelle de Paris, 567-606.

Cardozo, N. 2008, Trishear in 3D. Algorithms, implementation, and limitations. Journal of Structural 453

Camanni, G., Roche, V., Childs, C., Manzocchi, T., Walsh, J., Conneally, J., Saqab, M.M. and 456 Delogkos, E., 2019. The three-dimensional geometry of relay zones within segmented normal faults. Journal of Structural Geology, 129, p.103895.

Childs, C., Nicol, A., Walsh, J.J. and Watterson, J., 2003. The growth and propagation of 461

Coleman, A.J., Duffy, O.B. and Jackson, C.A-L., 2019. Growth folds above propagating normal

Conneally, J., Childs, C. and Nicol, A., 2017. Monocline formation during growth of segmented faults in the Taranaki Basin, offshore New Zealand. Tectonophysics, 721, 310-321.

Corfield, S.C., Sharp, I.R., (2000) Structural style and stratigraphic architecture of fault-propagation Norway. Basin Research, 12, 329-341. 
Deckers, J., 2015. Decoupled extensional faulting and forced folding in the southern part of the Roer Valley Graben, Belgium. Journal of Structural Geology, 81, 125-134.

El-Wahed, M.A., Ashmawy, M., Tawfik, H. 2010. Structural setting of Cretaceous pull-apart basins and Miocene extensional folds in the Quseir-Umm Gheig region, northwestern Red Sea, Egypt. Lithosphere 2, 13-32.

Ferrill, D.A. and Morris, A.P., 2008. Fault zone deformation controlled by carbonate mechanical stratigraphy, Balcones fault system, Texas. AAPG Bulletin, 92, 359-380.

Ferrill, D.A., Morris, A.P. and Smart, K.J., 2007. Stratigraphic control on extensional fault propagation folding: Big Brushy Canyon monocline, Sierra del Carmen, Texas. Geological Society, London, Special Publications, 292, 203-217.

Ferrill, D.A., Morris, A.P. and McGinnis, R.N., 2012. Extensional fault-propagation folding in mechanically layered rocks: The case against the frictional drag mechanism. Tectonophysics, $576,78-85$.

Finch, E., Hardy, S. and Gawthorpe, R., 2004. Discrete-element modelling of extensional fault-propagation folding above rigid basement fault blocks. Basin research, 16, 467-488.

Ford, M., Le Carlier de Veslud, C., Bourgeois, O., 2007. Kinematic and geometric analysis of faultrelated folds in a rift-setting: The Dannemarie basin, Upper Rhine Graben, France. Journal of Structural Geology 29, 1811-1830.

Fossen, H., Rotevatn, A., 2016. Fault linkage and relay structures in extensional settings-A review. Earth-Science Reviews, 154, 14-28.

Freitag, U.A., Sanderson, D.J., Lonergan, L. and Bevan, T.G., 2017. Comparison of upwards splaying and upwards merging segmented normal faults. Journal of Structural Geology, 100, 1-11.

Garfunkel, Z., Bartov, Y., 1977. Tectonics of the Suez Rift. Geological Survey of Israel Bulletin 71, $1-41$.

Gawthorpe, R.L., Sharp, I., Underhill, J.R. and Gupta, S., 1997. Linked sequence stratigraphic and structural evolution of propagating normal faults. Geology, 25, 795-798. 
516 Gawthorpe, R.L., Jackson, C.A.L., Young, M.J., Sharp, I.R., Moustafa, A.R., Leppard, C.W., 2003.

517 Normal fault growth, displacement localisation and the evolution of normal fault populations: the Hammam Faraun fault block, Suez Rift, Egypt. Journal of Structural Geology 25, 883-895.

Gawthorpe, R.L., Leeder, M., 2000. Tectono-sedimentary evolution of active extensional basins. Basin Research 12, 195-218.

Giba, M., Walsh, J.J. and Nicol, A., 2012. Segmentation and growth of an obliquely reactivated normal fault. Journal of Structural Geology, 39, 253-267.

Gupta, S., Underhill, J.R., Sharp, I.R., Gawthorpe, R.L., 1999. Role of fault interactions in controlling synrift sediment dispersal patterns: Miocene, Abu Alaqa Group, Suez Rift, Sinai, Egypt. Basin

Hardy, S., McClay, K., 1999. Kinematic modelling of extensional fault propagation folding. Journal Research 11, 167-189.

Hardy, S. and Finch, E., 2006. Discrete element modelling of the influence of cover strength on

Jackson, C.A.L. and Rotevatn, A., 2013. 3D seismic analysis of the structure and evolution of a saltinfluenced normal fault zone: a test of competing fault growth models. Journal of Structural

Janecke, S.U., Vanderburg, C.J., Blankenau, J.J., 1998. Geometry, mechanism, and significance of Geology, 54, 215-234.

Keller, J.V.A. and Lynch, G., 1999. Displacement transfer and forced folding in the Maritimes basin Journal of Structural Geology 24, 743-762. 
554 Krebs, W.N., Wescott, W.A., Nummedal, D., Gaafar, I., Azazi, G., Karamat, S., 1997. Graphic correlation and sequence stratigraphy of Neogene rocks in the Gulf of Suez. Bulletin of the Geological Society of France 168, 63-71.

Lăpădat, A., Imber, J., Yielding, G., Iacopini, D., McCaffrey, K.J., Long, J.J. Jones, R.R., 2017. Occurrence and development of folding related to normal faulting within a mechanically heterogeneous sedimentary sequence: a case study from Inner Moray Firth, UK. Geological Society, London, Special Publications, 439, 373-394.

Lewis, M.M., Jackson, C.A-L. and Gawthorpe, R.L., 2013. Salt-influenced normal fault growth and forced folding: The Stavanger Fault System, North Sea. Journal of Structural Geology, 54, 156-

Lewis, M.M., Jackson, C.A-L., Gawthorpe, R.L. and Whipp, P.S., 2015. Early synrift reservoir development on the flanks of extensional forced folds: A seismic-scale outcrop analog from the

Lewis, M.M., Jackson, C.A-L. and Gawthorpe, R.L., 2017. Tectono-sedimentary development of early syn-rift deposits: the Abura Graben, Suez Rift, Egypt. Basin Research, 29, 327-351.

Long, J.J. and Imber, J., 2011. Geological controls on fault relay zone scaling. Journal of Structural Geology, 33, 1790-1800.

Lyberis, N., 1988. Tectonic evolution of the Gulf of Suez and the Gulf of Aqaba. Tectonophysics 153, 209-220.

Maurin, J.-C., Niviere, B., 2000. Extensional forced folding and decollement of the pre-rift series along the Rhine Graben and their influence on the geometry of the syn-rift sequences. In:

McClay, K.R., Nichols, G.J., Khalil, S.M., Darwish, M., Bosworth, W., 1998. Extensional tectonics Cosgrove, J.W., Ameen, M.S. (Eds.), Forced Folds and Fractures, Geological Society of London and sedimentation, eastern Gulf of Suez, Egypt. In: Purser, B.H., Bosence, D.W.J. (Eds.) Sedimentation and Tectonics of Rift Basins: Red Sea-Gulf of Aden, Chapman Hall, London, 223-238. 
Moustafa, A.R., 1987. Drape folding in the Baba-Sidri area, eastern side of the Suez Rift, Egypt. Journal of Geology 31, 15-27.

Moustafa, A.R., 1992, The Feiran tilted blocks: an example of a synthetic transfer zone, eastern side of the Suez rift. Annales Tectonicæ, 6, 193-201.

Moustafa, A.R., 1996. Internal structure and deformation of an accommodation zone in the northern part of the Suez rift. Journal of Structural Geology 18, 93-107.

Moustafa, A.R., El-Raey, A.K., 1993. Structural Characteristics of the Suez rift margins. Geol Rundsch, 82, 101-109.

Pascoe, R., Hooper, R., Storhaug, K. and Harper, H., 1999, January. Evolution of extensional styles at the southern termination of the Nordland Ridge, Mid-Norway: a response to variations in coupling above Triassic salt. In Geological Society, London, Petroleum Geology Conference series (Vol. 5, No. 1, pp. 83-90). Geological Society of London.

Patton, T.L., 1984. Normal faulting and fold development in sedimentary rocks above a pre-existing basement normal fault. Unpublished PhD thesis, Texas A \& M University.

Patton, T.L., Moustafa, A.R., Nelson, R.A., Abdine, S.A., 1994. Tectonic evolution and structural setting of the Suez Rift. In: Landon, S.M. (Ed.), Interior Rift Basin American Association of Petroleum Geologists Memoir 59, 7-55.

Schöpfer, M.P.J., Childs, C., Walsh, J.J., 2006. Localisation of normal faults in multilayer sequences. Journal of Structural Geology 28, 816-833.

Schöpfer, M.P.J., Childs, C., Walsh, J.J., Manzocchi, T., Koyi, H.A., 2007. Geometrical analysis of the refraction and segmentation of normal faults in periodically layered sequences. Journal of Structural Geology 29, 318-335.

Schlische, R.W., 1995. Geometry and origin of fault-related folds in extensional settings. American Association of Petroleum Geologists Bulletin 79, 1661-1678.

Sharp, I.R., Gawthorpe, R.L., Underhill, J.R., Gupta, S., 2000. Fault-propagation folding in extensional settings: Examples of structural style and synrift sedimentary response from the Suez rift, Sinai, Egypt. Geological Society of America Bulletin 112, 1877-1899. 
628 Stearns, D.W., 1978, Faulting and forced folding in the Rocky Mountain foreland, in Matthews, V.I., ed., Laramide folding associated with basement block faulting in the western United States: Boulder, Colorado, Geological Society of America Memoir 151, p. 1-37.

Stewart, M.E., Taylor, W.J., 1996. Structural analysis and fault segment boundary identification along the Hurricane fault in southwestern Utah. Journal of Structural Geology 18, 1017-1029.

Tavani, S., Carola, E., Granado, P., Quintà, A. and Muñoz, J.A., 2013. Transpressive inversion of a Mesozoic extensional forced fold system with an intermediate décollement level in the

Tavani, S. and Granado, P., 2015. Along-strike evolution of folding, stretching and breaching of supra-salt strata in the Plataforma Burgalesa extensional forced fold system (northern Spain).

642

Tavani, S., Balsamo, F. and Granado, P., 2018. Petroleum system in supra-salt strata of extensional

van der Zee, W. and Urai, J.L., 2005. Processes of normal fault evolution in a siliciclastic sequence: a case study from Miri, Sarawak, Malaysia. Journal of Structural Geology, 27, 2281-2300.

Walsh, J.J., Bailey, W.R., Childs, C., Nicol, A., Bonson, C.G., 2003. Formation of segment normal 651

Walsh, J.J., Watterson, J., Bailey, W.R., Childs, C., 1999. Fault relays, bends and branch-lines. Journal of Structural Geology, 21, 1019-1026.

Walsh, J.R., Watterson, J., 1991. Geometric and kinematic coherence and scale effects of normal fault systems. In; Roberts, A.M., Yielding, G., Freemen, B. (Eds.) The Geometry of Normal Faults. Geological Society of London Special Publication, 186, 157-170.

Walsh, J.J., Nicol, A. and Childs, C., 2002. An alternative model for the growth of faults. Journal of 
Walsh, J.J., Bailey, W.R., Childs, C., Nicol, A. and Bonson, C.G., 2003. Formation of segmented normal faults: a 3-D perspective. Journal of Structural Geology, 25, 1251-1262.

Whipp, P.S., Jackson, C.A.L., Gawthorpe, R.L., Dreyer, T. and Quinn, D., 2014. Normal fault array evolution above a reactivated rift fabric; a subsurface example from the northern Horda Platform, Norwegian North Sea. Basin Research, 26, 523-549.

Whipp, P.S., Jackson, C.L., Schlische, R.W., Withjack, M.O. and Gawthorpe, R.L., 2017. Spatial distribution and evolution of fault-segment boundary types in rift systems: observations from experimental clay models. Geological Society, London, Special Publications, 439, 79-107.

Wilson, P., Gawthorpe, R.L., Hodgetts, D., Rarity, F., Sharp, I.R., 2009. Geometry and architecture of faults in a syn-rift normal fault array: The Nukhul half-graben, Suez rift, Egypt. Journal of Structural Geology, 31, 759-775.

Wilson, P., Elliott, G.M., Gawthorpe, R.L., Jackson, C.A.L., Michelsen, L. and Sharp, I.R., 2013. Geometry and segmentation of an evaporite-detached normal fault array: 3D seismic analysis of the southern Bremstein Fault Complex, offshore mid-Norway. Journal of Structural Geology, 51, 74-91.

Willsey, S.P., Umhoefer, P.J., Hilley, G.E., 2002. Early evolution of an extensional monocline by a propagating normal fault: 3D analysis from combined filed study and numerical modelling. Journal of Structural Geology 24, 651-669.

Withjack, M. O., Olson, J., and Peterson, E., 1990, Experimental models of extensional forced folds: AAPG Bulletin, v. 74, p. 1038-1054.

\section{Figure captions}

Figure 1: (A) Physical analogue (clay) model showing the kinematic and structural development of an extensional growth fold (sensu Coleman et al., 2019) and associated secondary structures (modified from Withjack et al., 1990). Note the eventual development of a through-going 'master' fault in Stage II; this fault breaches the overlying extensional growth fold, which during Stage I is characterised by a basinward-facing, unbreached monocline. Reverse faults are shown in red. (b) Result of a trishear-based model, showing the kinematic and structural development of an extensional forced fold (modified from Jackson et al., 2006) (based on the kinematic model of Allmendinger, 1998; see also Hardy \& McClay, 1999). Note again the presence of steep-dipping reverse faults in the 
immediate (proto-)hangingwall of the through-going master fault. (c) 2D profile from a 3D seismic reflection volume from the Northern North Sea, showing the final structure of a breached extensional fault-propagation fold. Note the development of reserve faults in the immediate hangingwall of the now through-going master fault. (d) Block diagram showing the change in structural style along-strike of a simple, isolated normal fault segment associated with extensional growth folding.

Figure 2: (A) Simplified geologic map of the El Qaa Fault Block (modified from Moustafa, 1993 and Sharp et al., 2000). B-SF=Baba-Sidri Fault; NF=Nezzazat Fault; $C F B=$ Coastal Fault Belt; FTZ=Feiran Transfer Zone; EBFB=Eastern Boundary Fault Belt; HFS=Hadahid Fault System; $\mathrm{GF}=$ Gebah Fault; SMF=Sinai Massif Fault; HFB=Hadahid Fault Block. Inset map shows the regional plate tectonic setting of the Gulf of Suez Rift. Dark-grey shading indicates area containing structures and stratigraphic units related to Oligo-Miocene rifting. (B) Geoseismic section across the central dip province of the Gulf of Suez Rift (modified from Patton et al., 1994). Location of the section is shown in $(\mathrm{A})$.

714

715 Figure 3: (A) Simplified geologic map of the Hadahid Fault Block (see Fig. 2A for location) (based on Moustafa, 1993 and new mapping undertaken as part of this study). The locations of cross-section in Fig. 4 are indicated. (B) Simplified geological map highlighting the constituent segments of the Hadahid Fault System.

Figure 4: Cross-sections through the Hadahid Fault Block from south to north, based on the mapping of Moustafa (1993) and Sharp et al. (2000), and mapping undertaken as part of this study. Locations of the cross-sections are shown in Fig. 3A. Vertical exaggeration=2. Colour key to stratigraphic units is shown in Fig. 3A. The mapped and inferred location of the Hadahid Fault System is shown (see text for full discussion). Note that all topographic profiles shown here and in other figures are constructed using $30 \mathrm{~m}$ ASTM DEM data (vertical exaggeration=x2). The geometry of the hangingwall of the Hadahid Fault System, especially on the southern segments, is largely unconstrained due to burial; it is inferred based on the measured thickness of the pre-rift succession (Fig. 3), and geometries predicted by physical and numerical models, and observed in natural examples of extensional growth folds (Fig. 1).

Figure 5: Composite stratigraphic section of the Hammam Faraun and El-Qaa fault blocks (modified from Moustafa, 1987). Mudstone-dominated units represent major layer-parallel slip horizons and are indicated by opposing black arrows. Bed thickness is based on measurements across the Hadahid Fault Block, with the recorded ranges being comparable to those reported by Moustafa and El-Raey (1993). The thickness of Megasequence One is taken from the Hammam Faraun Fault Block (Sharp et 
stratigraphic surfaces bounding early syn-rift units are also indicated (Bentham et al., 1996; Krebs et al., 1997).

Figure 6: (A) Field map of the southern end of the Hadahid Fault System, showing the Gebah and Abura segments. Colour key to stratigraphic units is shown in Fig. 3A. Red dots indicate the approximate boundaries between the identified segments. Lower hemisphere projection stereonets summarise the dip and dip direction of pre- and syn-rift bedding (A-G; location shown on map). The location of the photographs shown in Figs 7, 11 and 13, and the cross-sections shown in (B) and (C), are indicated. (B) Down-plunge cross-section across the Gebah Segment. (C) Down-plunge crosssection across the Abura Segment.

Figure 7: Photograph looking northwards along the Sinai Massif and Gebah faults, showing the branchpoint with the Gebah Segment of the Hadahid Fault System. The location of the photo is shown in Fig. 6A.

Figure 8: (A) Field map of the Theghda Segment of the Hadahid Fault System. Colour key to stratigraphic units is shown in Fig. 3A. Red dots indicate the approximate boundaries between the identified segments. Lower hemisphere projection stereonets summarise the dip and dip direction of pre- and syn-rift bedding (A-D; location shown on map). Rose diagrams show the trend of fractures in pre-rift strata on the middle limb of the Thebes Formation-cored monocline. The location of the photograph shown in Fig. 9 and the cross-section shown in (B) are indicated. (B) Down-plunge crosssection across the Theghda Segment.

Figure 9: Photograph looking ESE, along strike of the Theghda Segment. The location of the photo location is shown in Fig. 8A.

Figure 10: (A) Field map of the Abyad Segment of the Hadahid Fault System. Colour key to stratigraphic units is shown in Fig. 3A. Red dots indicate the approximate boundaries between the identified segments. Lower hemisphere projection stereonets summarise the dip and dip direction of pre- and syn-rift bedding (A-G; location shown on map). Rose diagrams show the trend of fractures in pre-rift strata on the middle limb of the Thebes Formation-cored monocline. The location of the photograph shown in Fig. 11 and the cross-section shown in (B) are indicated. (B) Down-plunge cross-section across the Abyad Segment.

Figure 11: Photograph showing the structure of a 'secondary' normal fault zone associated with the 
774 Figure 12: (A) Field map of the Ratamat Segment of the Hadahid Fault System. Colour key to stratigraphic units is shown in Fig. 3A. Red dots indicate the approximate boundaries between the identified segments. Lower hemisphere projection stereonets summarise the dip and dip direction of pre- and syn-rift bedding (A-G; location shown on map). Rose diagrams show the trend of fractures in pre-rift strata. The location of the photograph shown in Fig. 13 and the cross-sections shown in (B) and (C) are indicated. (B) Down-plunge cross-section across the central part of the Ratamat Segment. (C) Down-plunge cross-section across the northern part of the Ratamat Segment.

Figure 13: (A) Photograph showing the structure of a 'secondary' normal fault zone associated with the Hadahid Fault System. (B) Photograph looking obliquely (to the NW) at the southern end of the Ratamat Segment of the Hadahid Fault System. The monocline limb is deformed by reverse faults which thrust older pre-rift over younger pre-rift strata (i.e. right-hand reverse fault), or pre- over synrift strata (i.e. left-hand reverse fault). (C) Photograph looking obliquely (to the $\mathrm{S}$ ) at the northern end of the Ratamat Segment. The Hadahid Fault System master fault is surface-breaching, and is inferred to lie to the $\mathrm{E}$ of the network of reverse faults that dissected the strongly rotated middle limb of a precursor monocline. The reverse fault-bound block of pre-rift Thebes Formation is thrust onto overturned syn-rift strata. Locations of the photos are shown in Figure 12A.

Figure 14: (A) Field map of the Hadahid Monocline and Hadahid fault (see also Fig. 16) segments of the Hadahid Fault System. Colour key to stratigraphic units is shown in Fig. 3A. Red dots indicate the approximate boundaries between the identified segments. Lower hemisphere projection stereonets summarise the dip and dip direction of pre- and syn-rift bedding (A-G; location shown on map). Rose diagrams show the trend of fractures in pre-rift strata. The location of the photograph shown in Fig. 15 and the cross-sections shown in (B) and (C) are indicated. (B) Down-plunge cross-section across the central part of the Hadahid Monocline Segment. (C) Down-plunge cross-section across the southcentral part of the Hadahid Monocline Segment. (D) Down-plunge cross-section across the southern part of the Hadahid Fault Segment.

802 Figure 15: Photograph looking northwards along the Hadahid Monocline Segment. Note the angular 803 discordance of $c .10^{\circ}$ between the pre-rift (Mokattam Formation) and overlying syn-rift strata (Nukhul Formation) (see Lewis et al., 2015). Location of the photo is shown in Figure 14A stratigraphic units is shown in Fig. 3A. Red dots indicate the approximate boundaries between the identified segments. Lower hemisphere projection stereonets summarise the dip and dip direction of pre- and syn-rift bedding (A-G; location shown on map). Rose diagrams show the trend of fractures in 
810 pre-rift strata. The location of the photograph shown in Fig. 17 and the cross-sections shown in (B)

811 are indicated. (B) Down-plunge cross-section across the central part of the Hadahid Fault Segment.

813 Figure 17: Photograph looking westwards along the Hadahid Fault Segment. Note the angular

814 discordance of $c .10^{\circ}$ between the pre-rift (Mokattam Formation) and overlying syn-rift strata (Nukhul

815 Formation) (see Lewis et al., 2015). Location of the photo is shown in Figure 16A.

816

817 Figure 18: (A) Field map of the Feiran monoclines segment of the Hadahid Fault System. Colour key

818 to stratigraphic units is shown in Fig. 3A. Red dots indicate the approximate boundaries between the

819 identified segments. Lower hemisphere projection stereonets summarise the dip and dip direction of

820 pre- and syn-rift bedding (A-G; location shown on map). Rose diagrams show the trend of fractures in

821 pre-rift strata. The location of the photograph shown in Fig. 19 and the cross-sections shown in (B)

822 are indicated. (B) Down-plunge cross-section across the West Feiran Monocline.

823

824 Figure 19: Photograph looking northwards along the middle limb of the East Feiran Monocline 825 Segment. Location of the photo is shown in Figure 18.

827 Figure 20. Schematic diagram summarising some of the key observations from the Hadahid Fault

828 System and outlining key structural elements of segmented normal fault-fault propagation fold 829 systems. Fault A is defined by an irregular upper tip-line elevation, superimposed on a net right-to-left 830 decrease in elevation and net fault displacement (i.e. the Hadahid Fault System); Fault B is defined by 831 an more smoothly decreasingly fault displacement and elevation of the upper tip-line. Footwall 832 anticline-hangingwall syncline pairs, which represent breached fault-propagation folds (monoclines) 833 and that flank the breaching faults, are not shown for clarity. 
Fig. 1

(a)
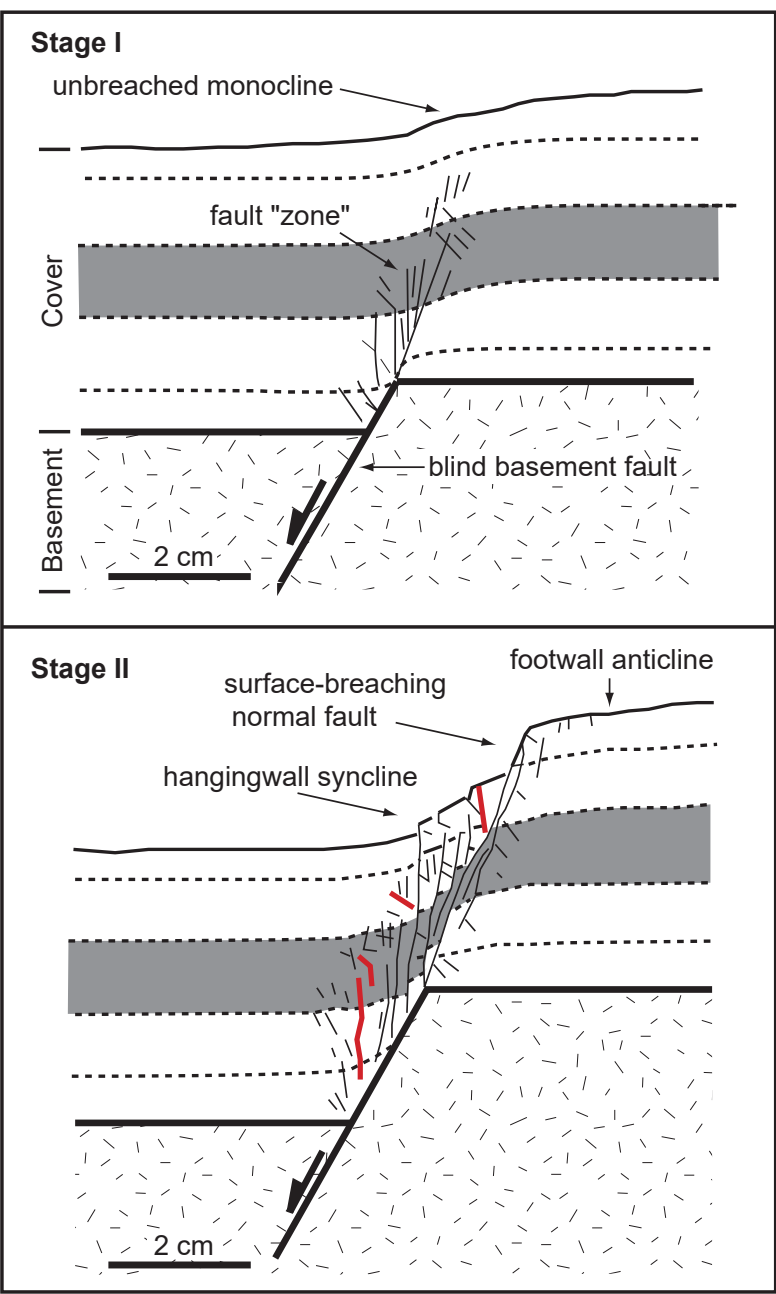

(b)

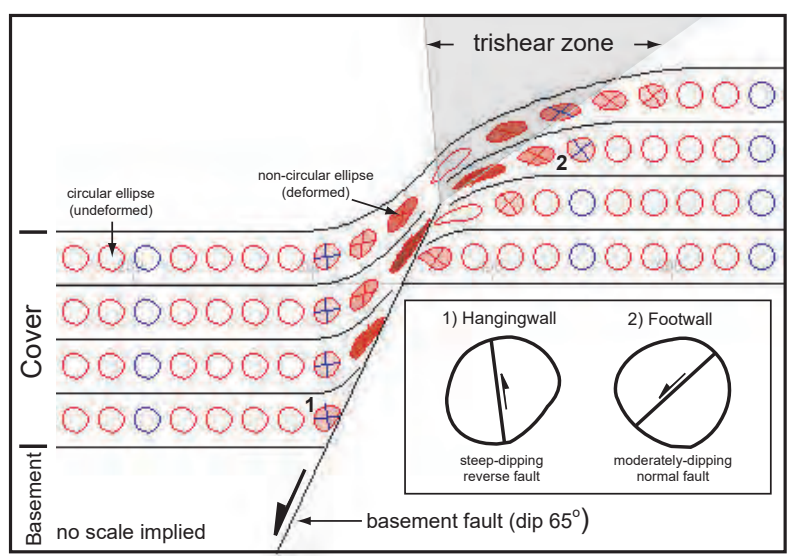

(c)

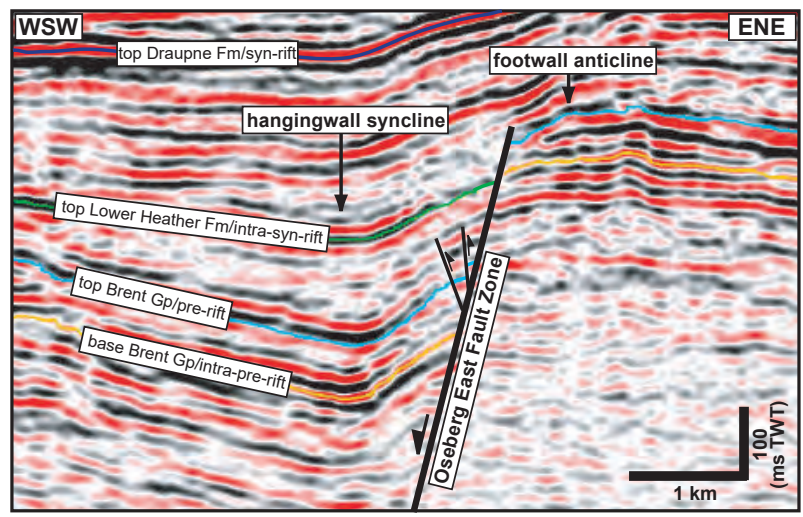

surface-breaching

normal fault/breached monocline

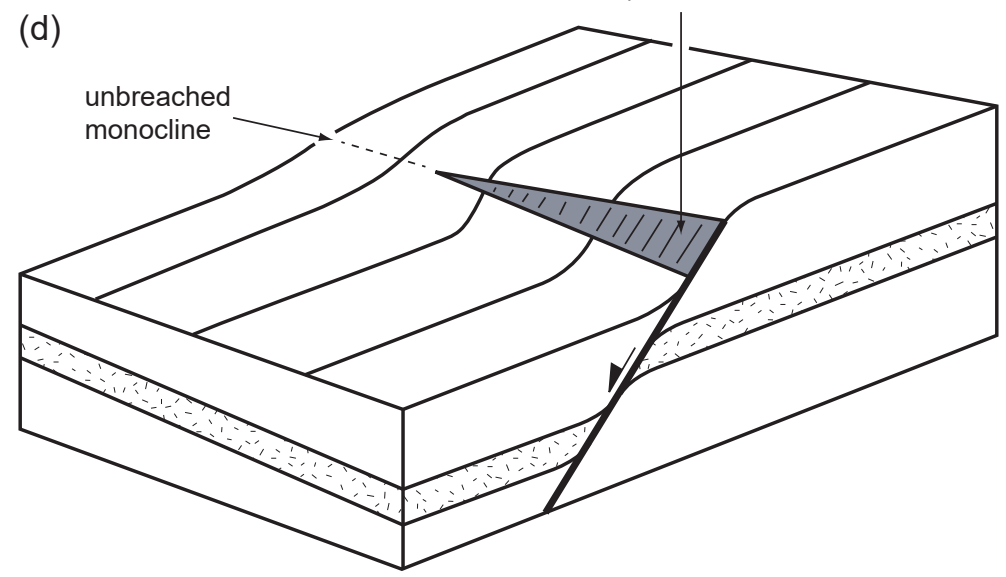


Fig.2

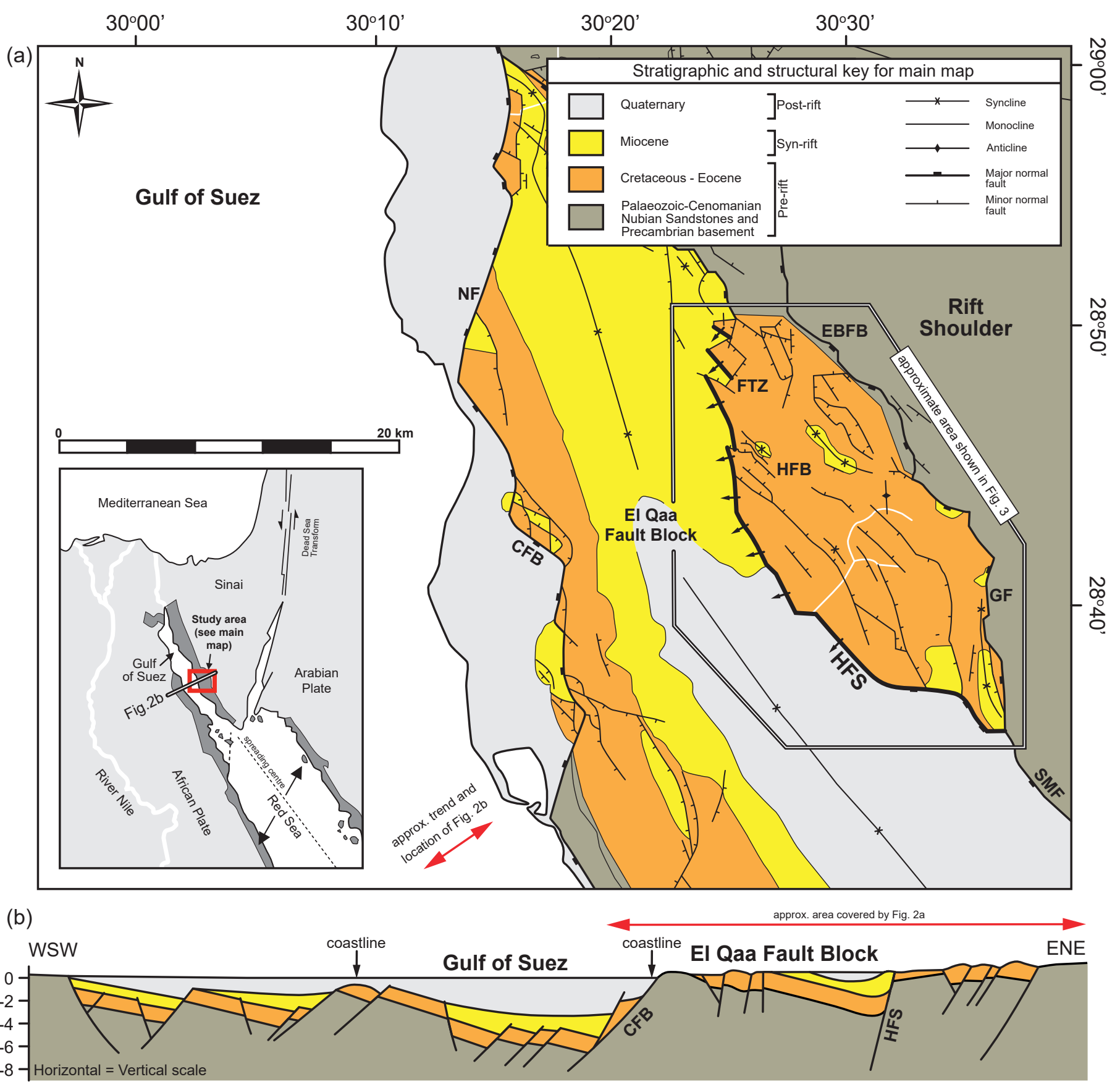



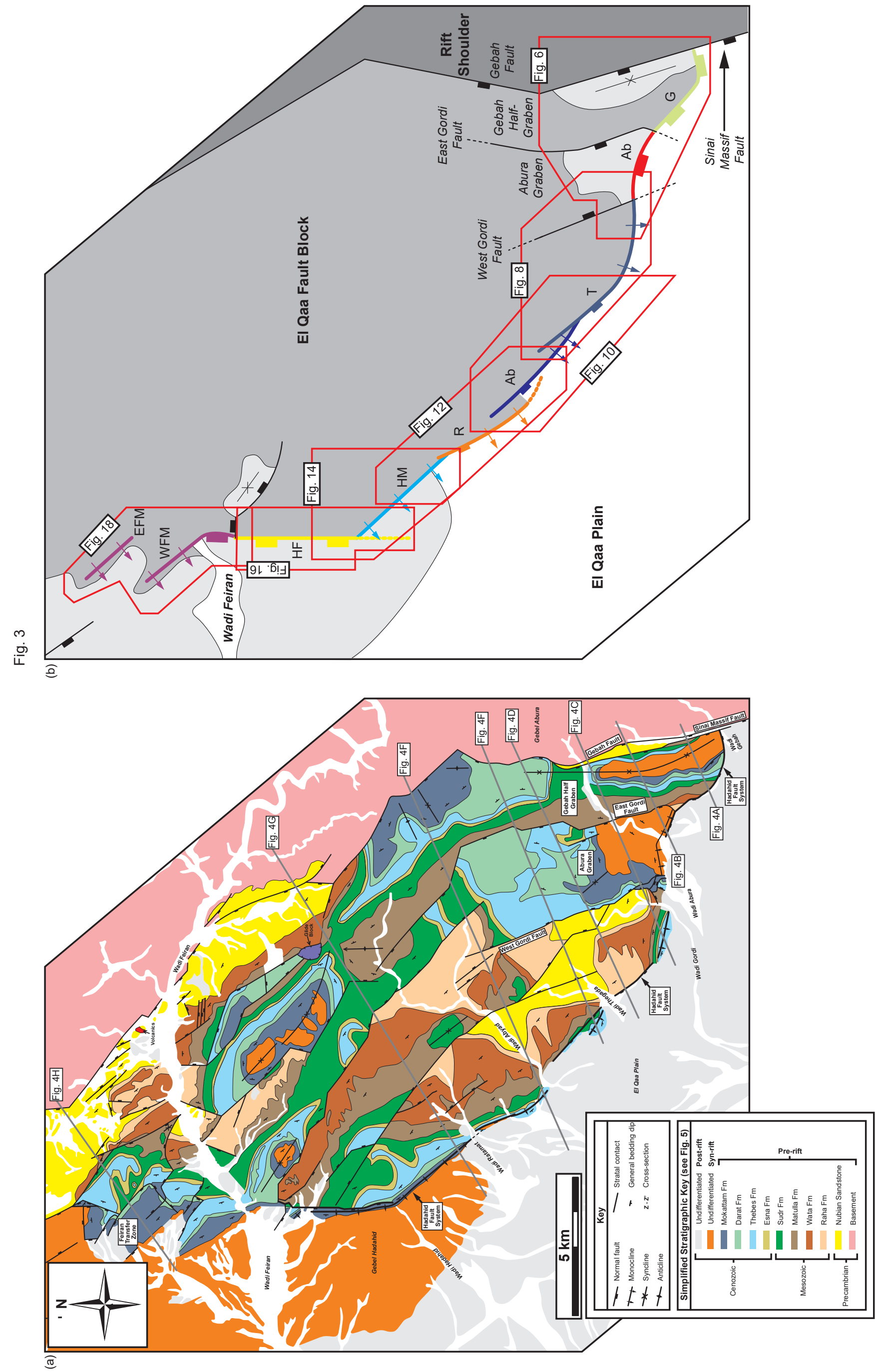

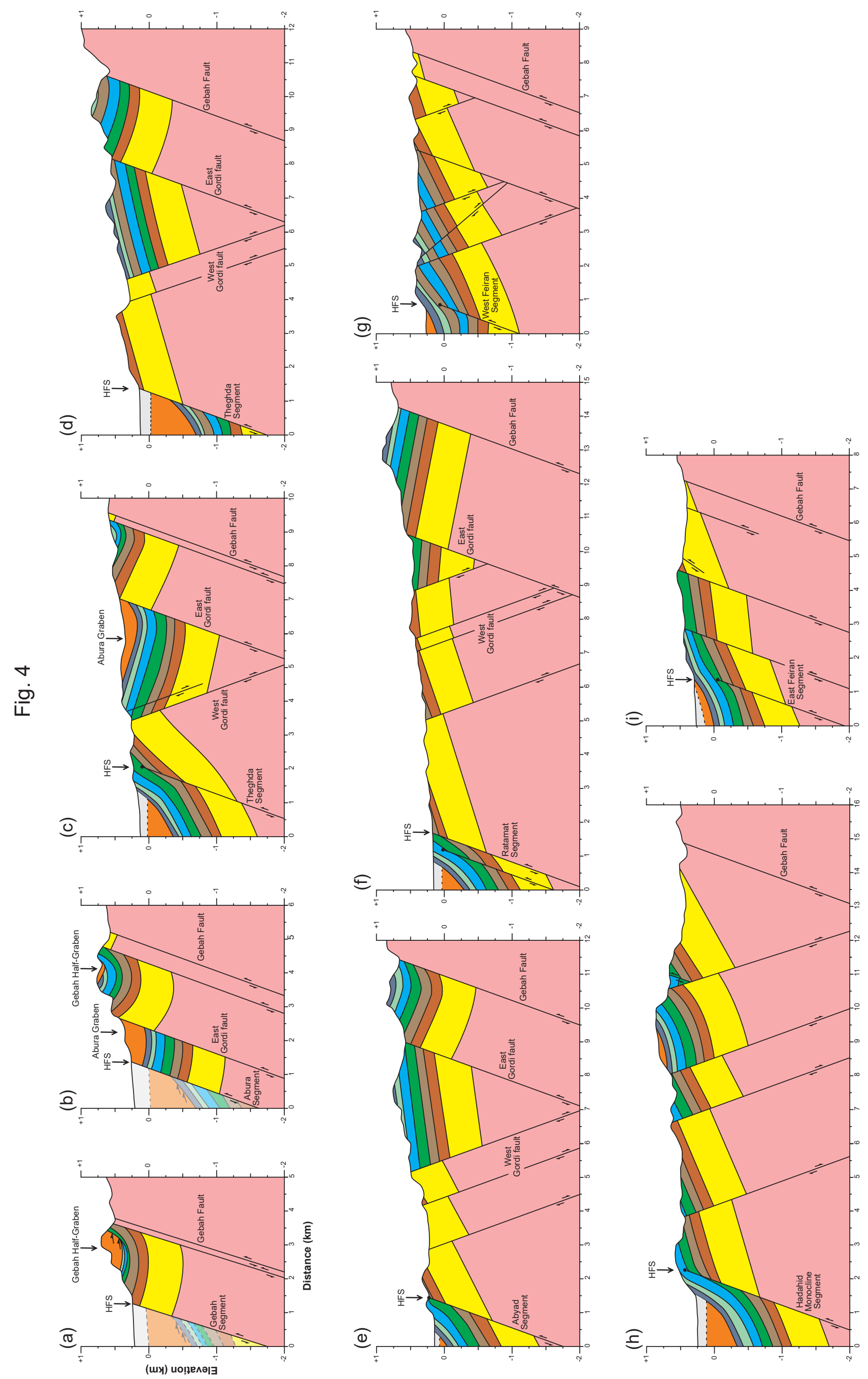
Fig. 5

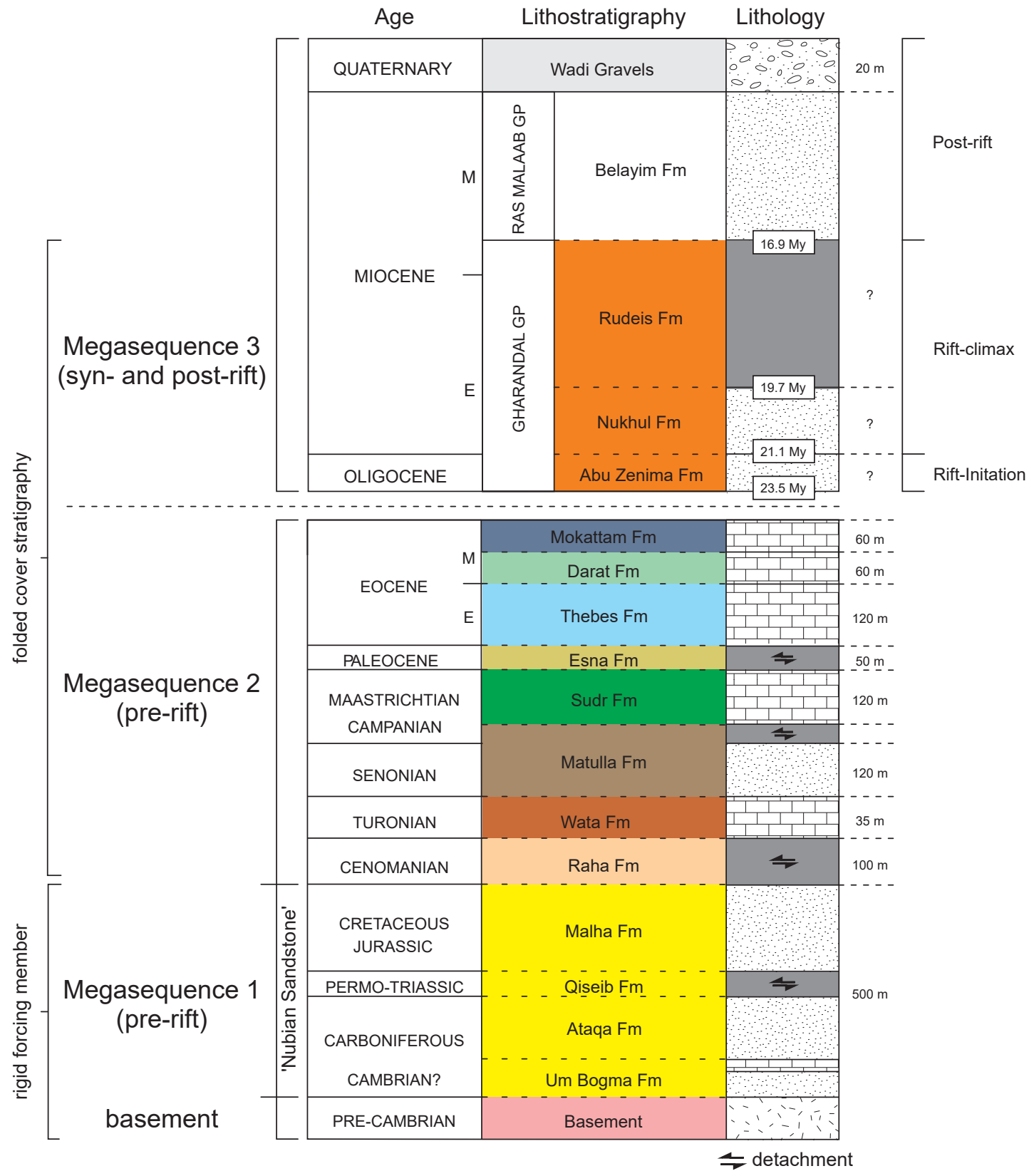

\begin{tabular}{|c|c|c|c|}
\hline \multicolumn{4}{|l|}{ Lithological Key } \\
\hline Mudstone/siltstone-dominated & 0 & Conglomerate-dominated & Metamorphic \\
\hline Sandstone-dominated & & Carbonate-dominated & \\
\hline
\end{tabular}


Fig. 6
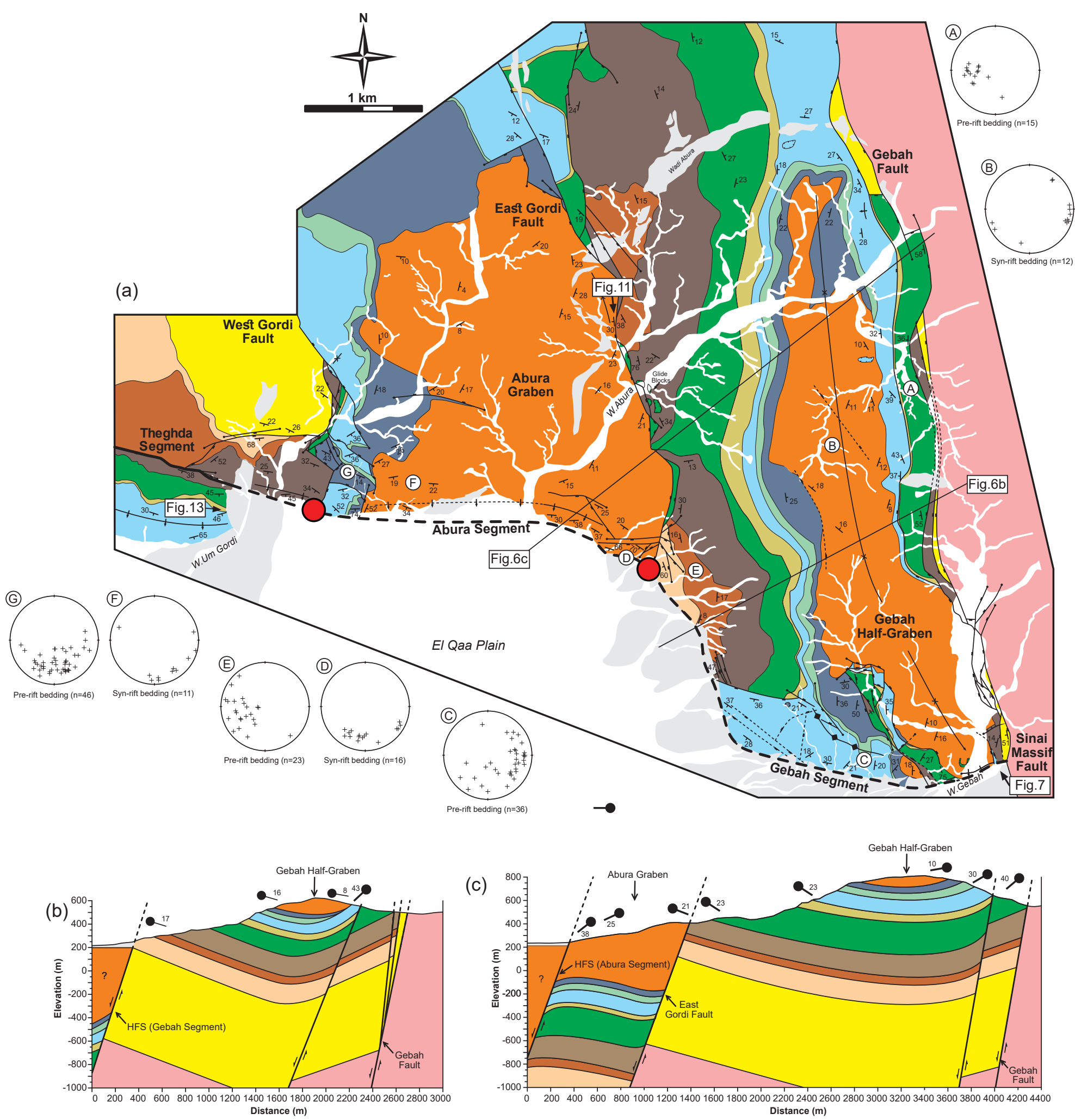


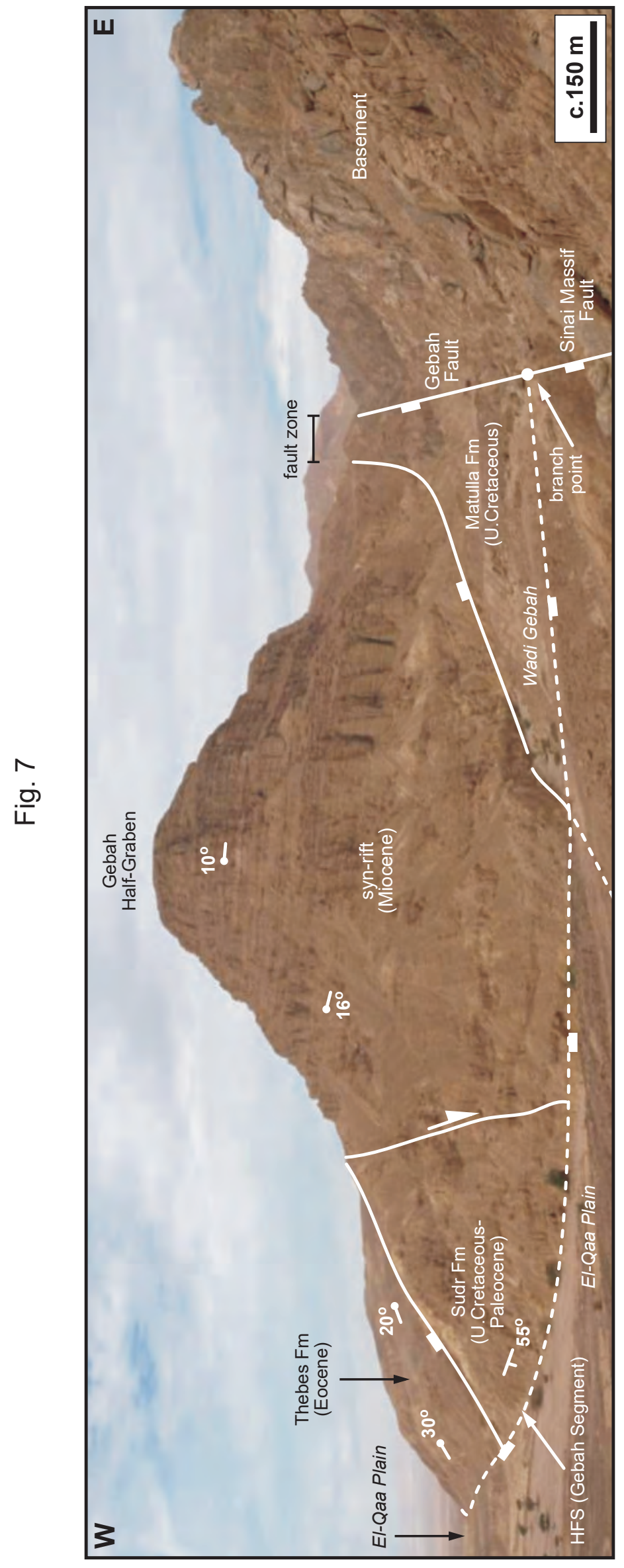


Fig. 8

(A)
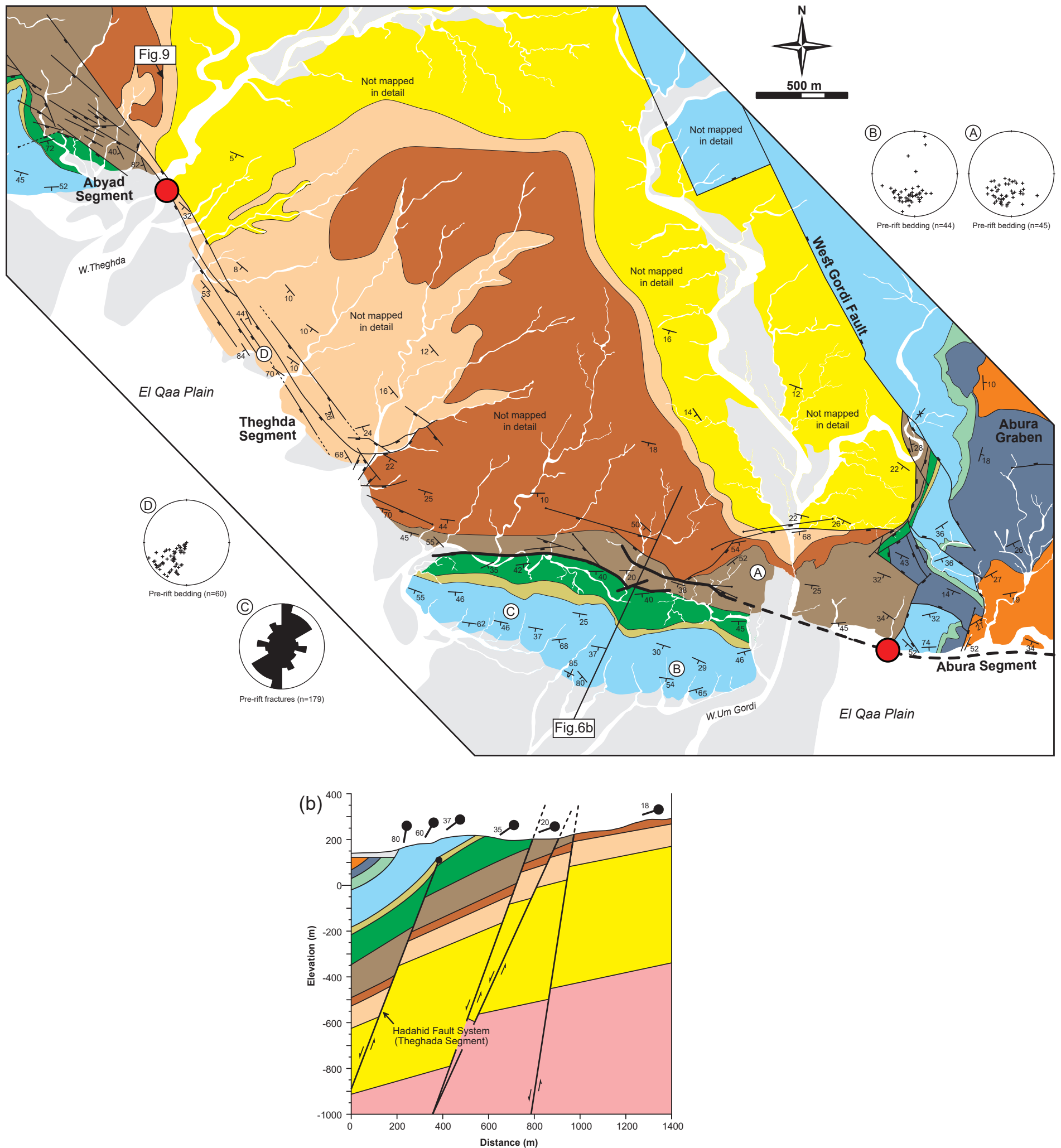
Fig.9

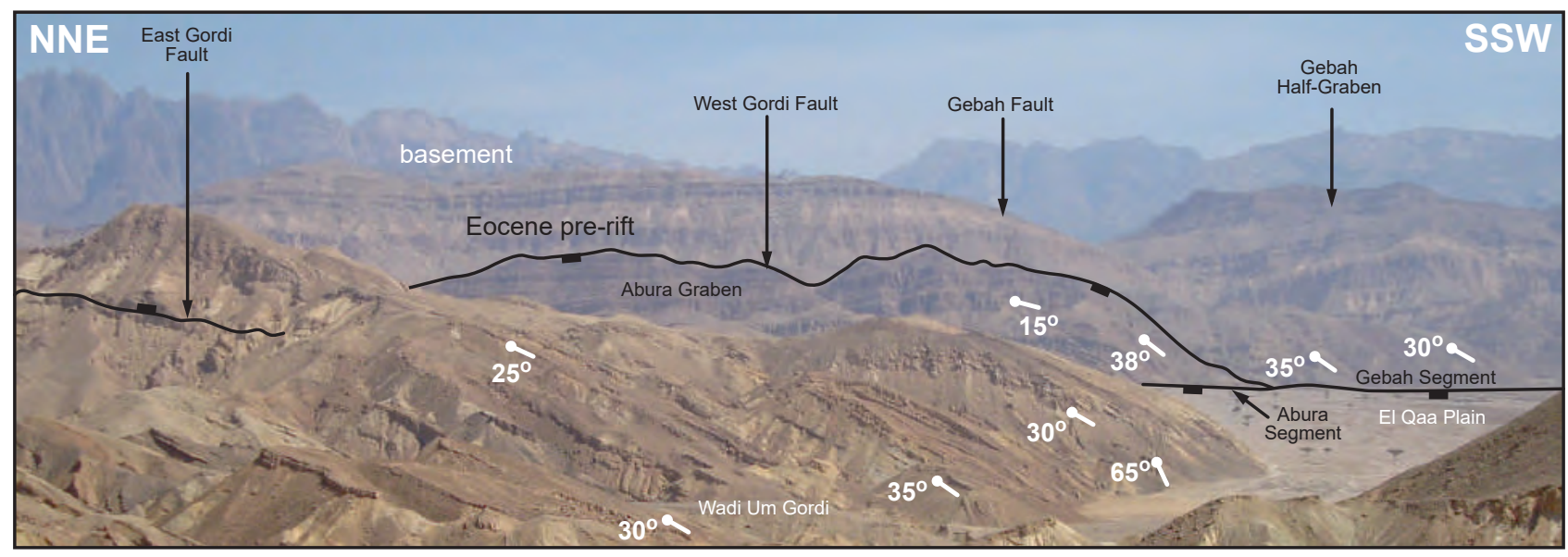


Fig. 10

(a)
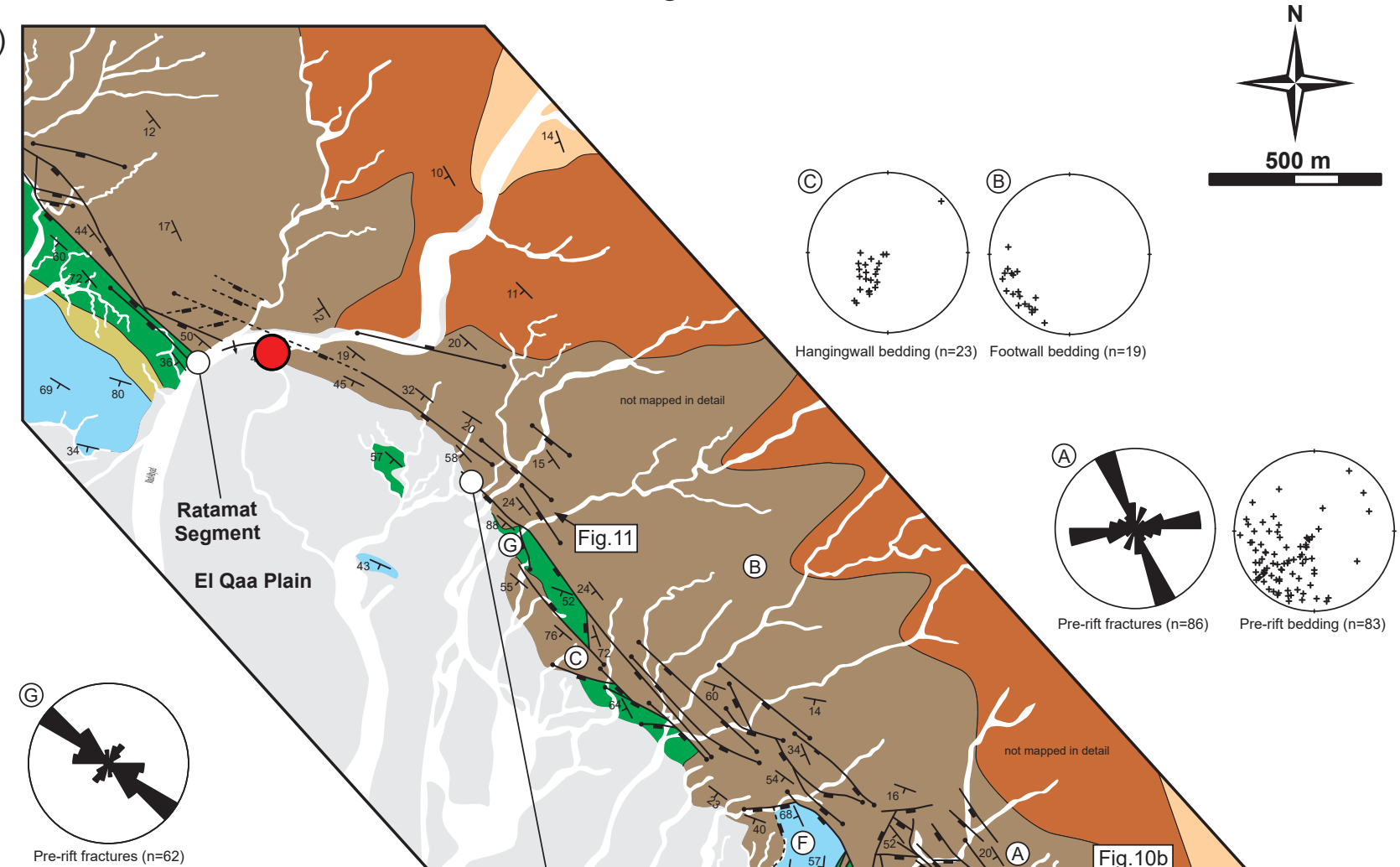

(b)
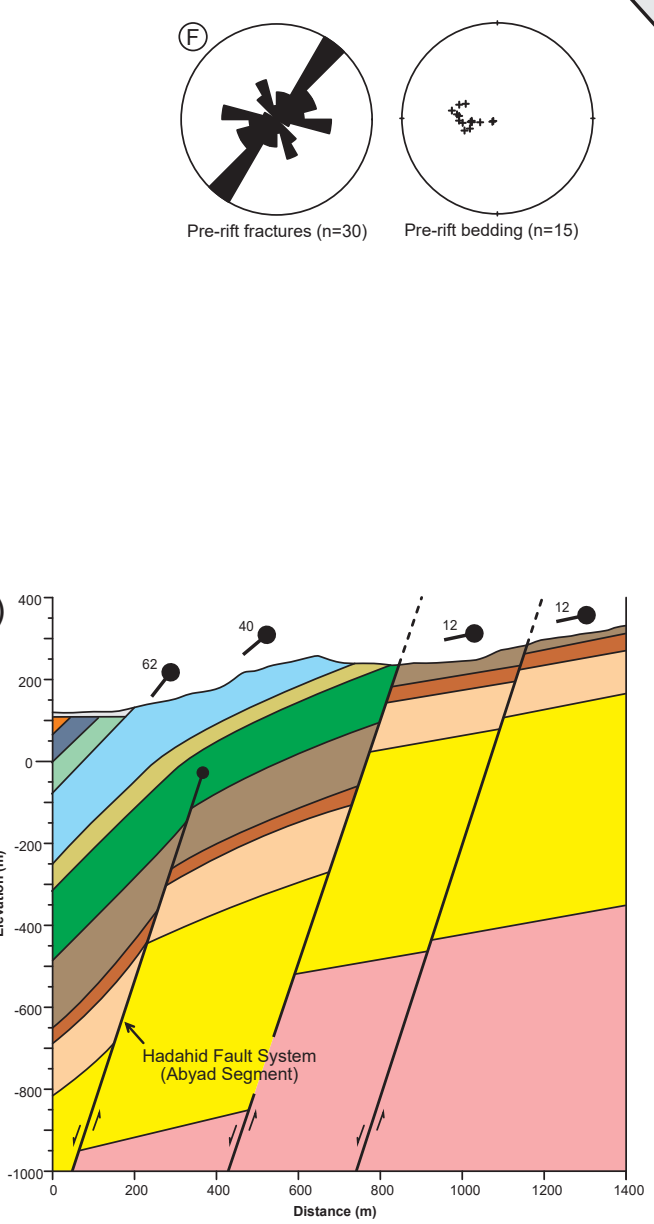

Abyad Segment
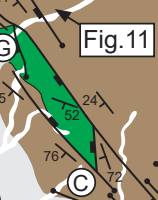
Fig. 11

SSE

NNW

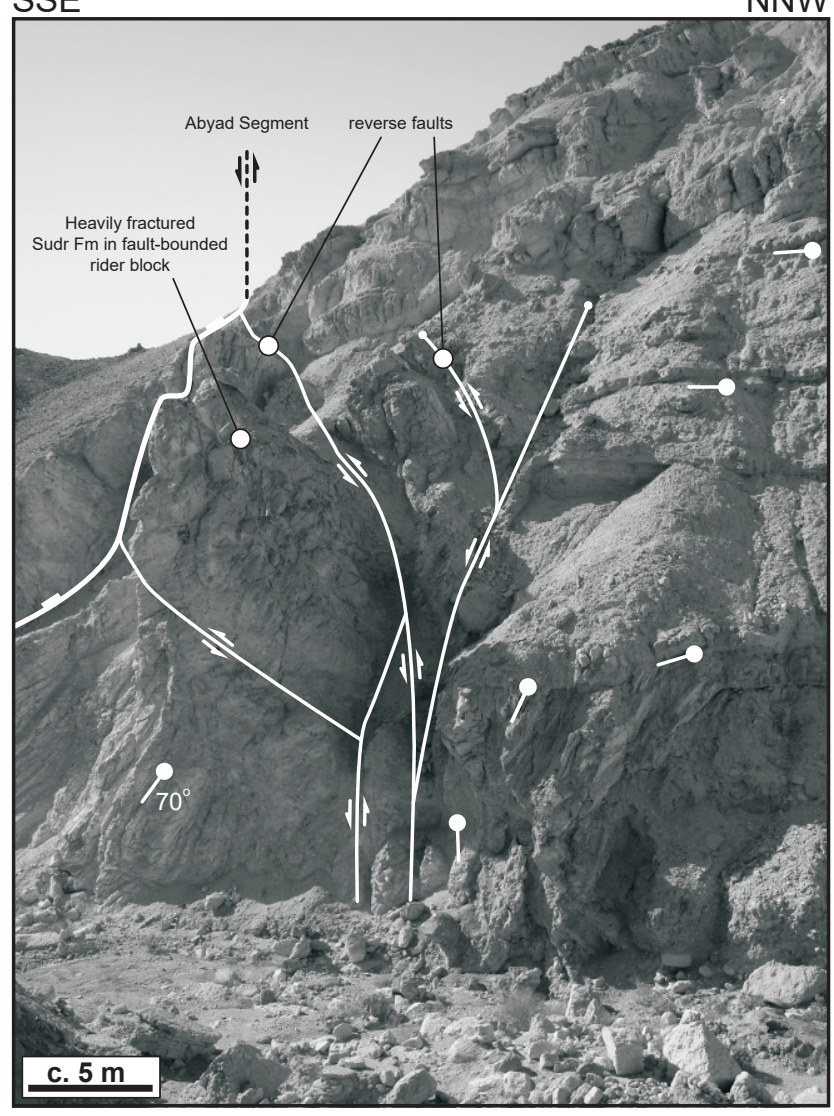


Fig.12

(a)

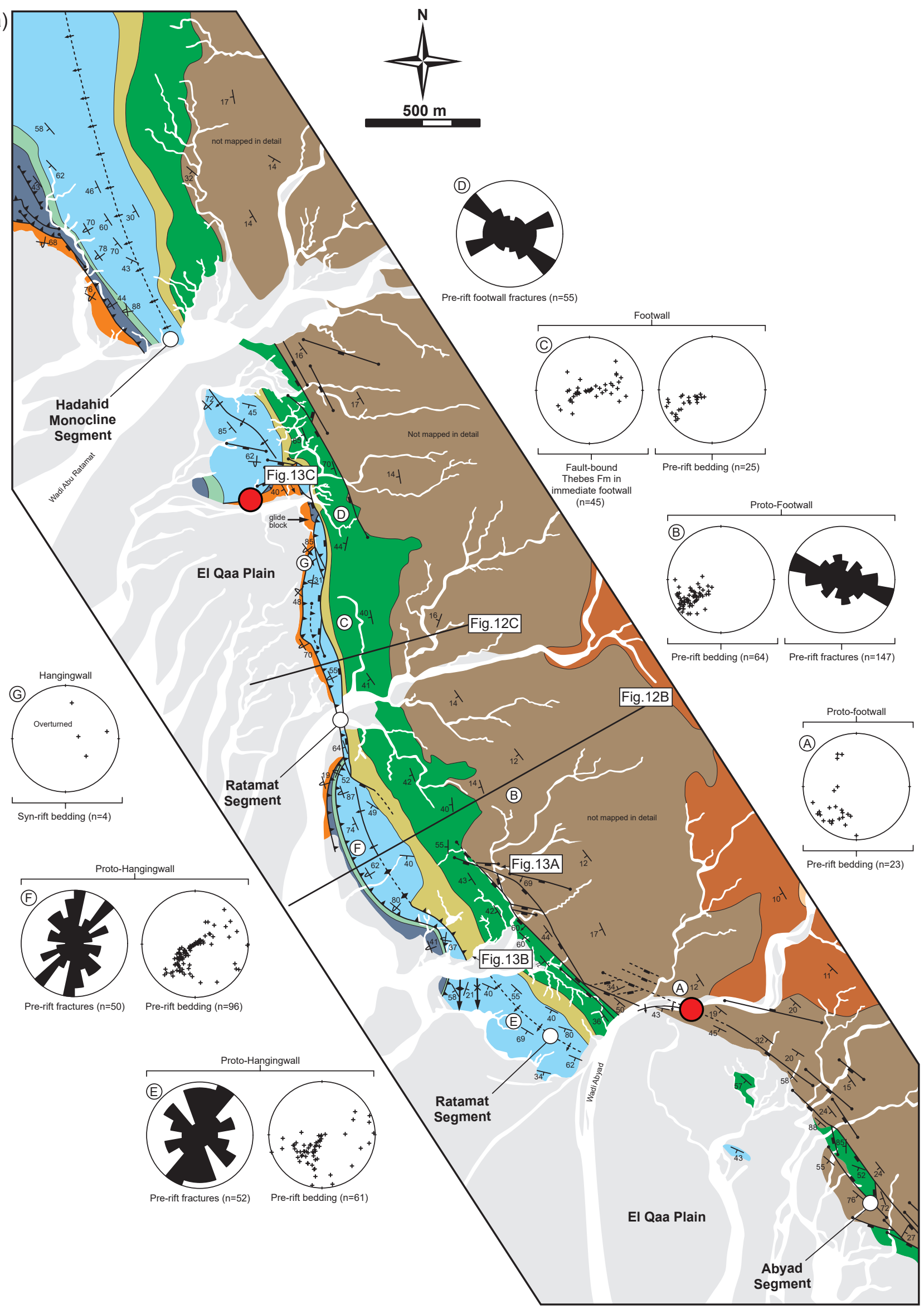

(b)

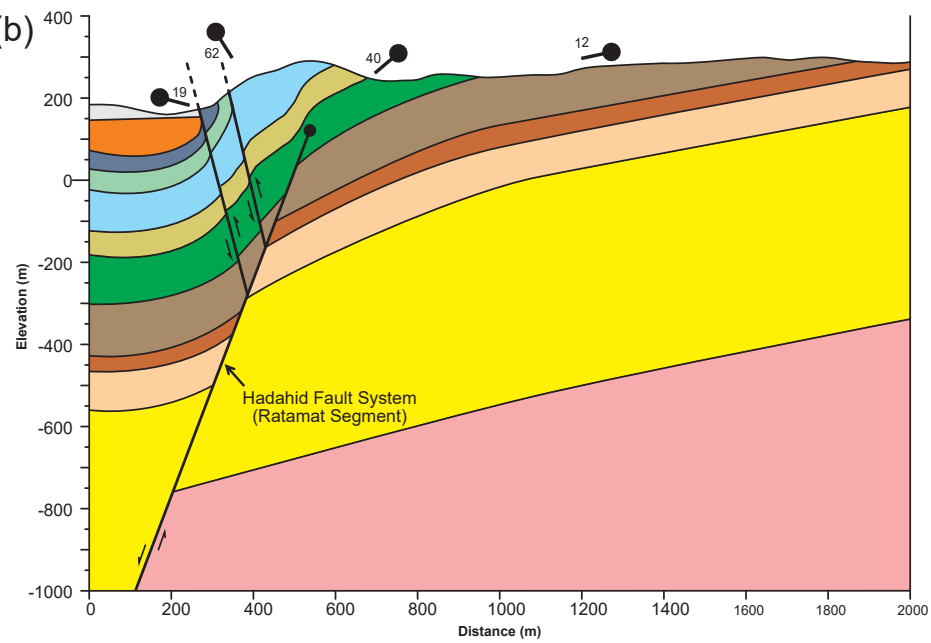

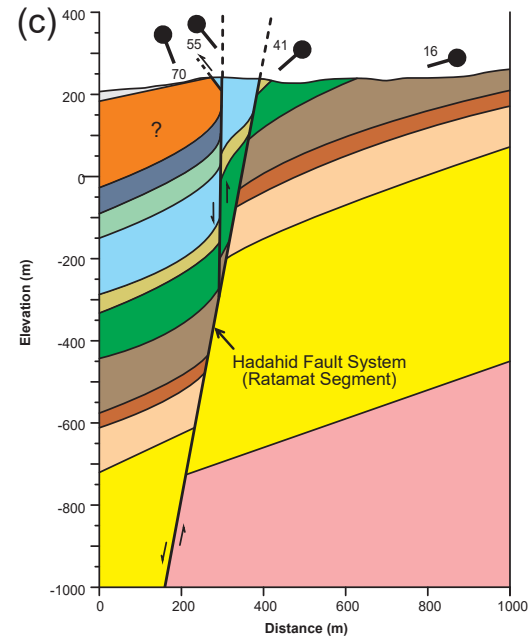



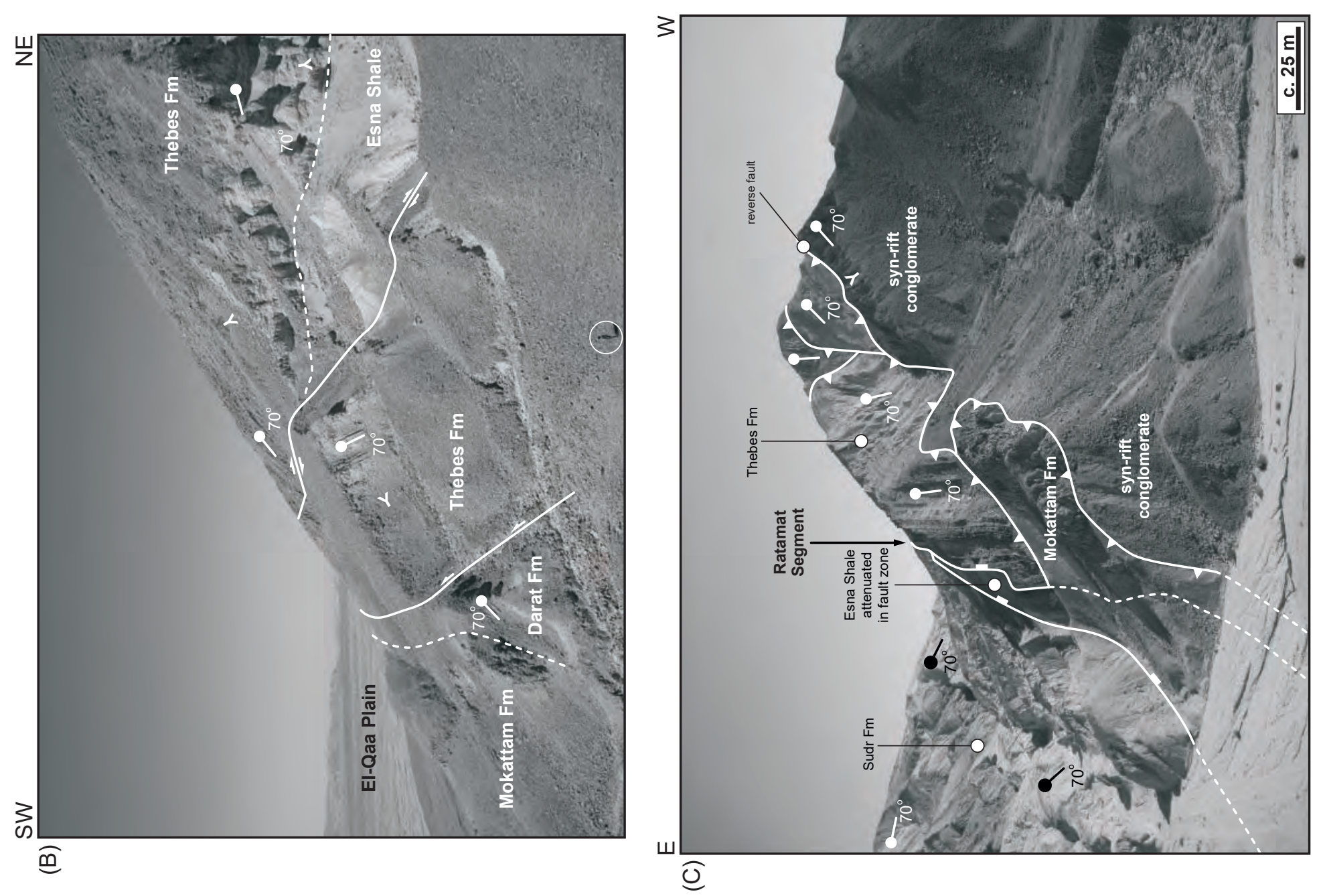

$\frac{0}{3}$

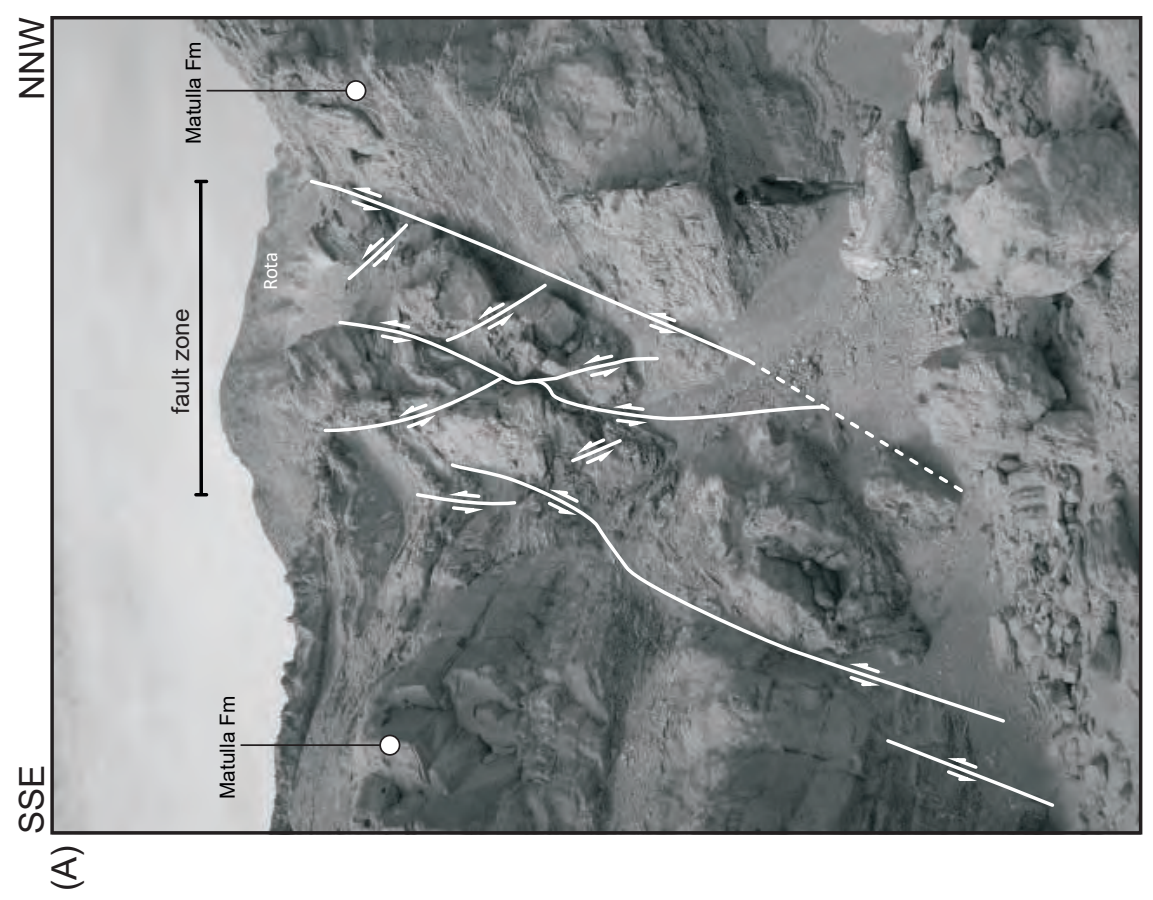


Fig. 14
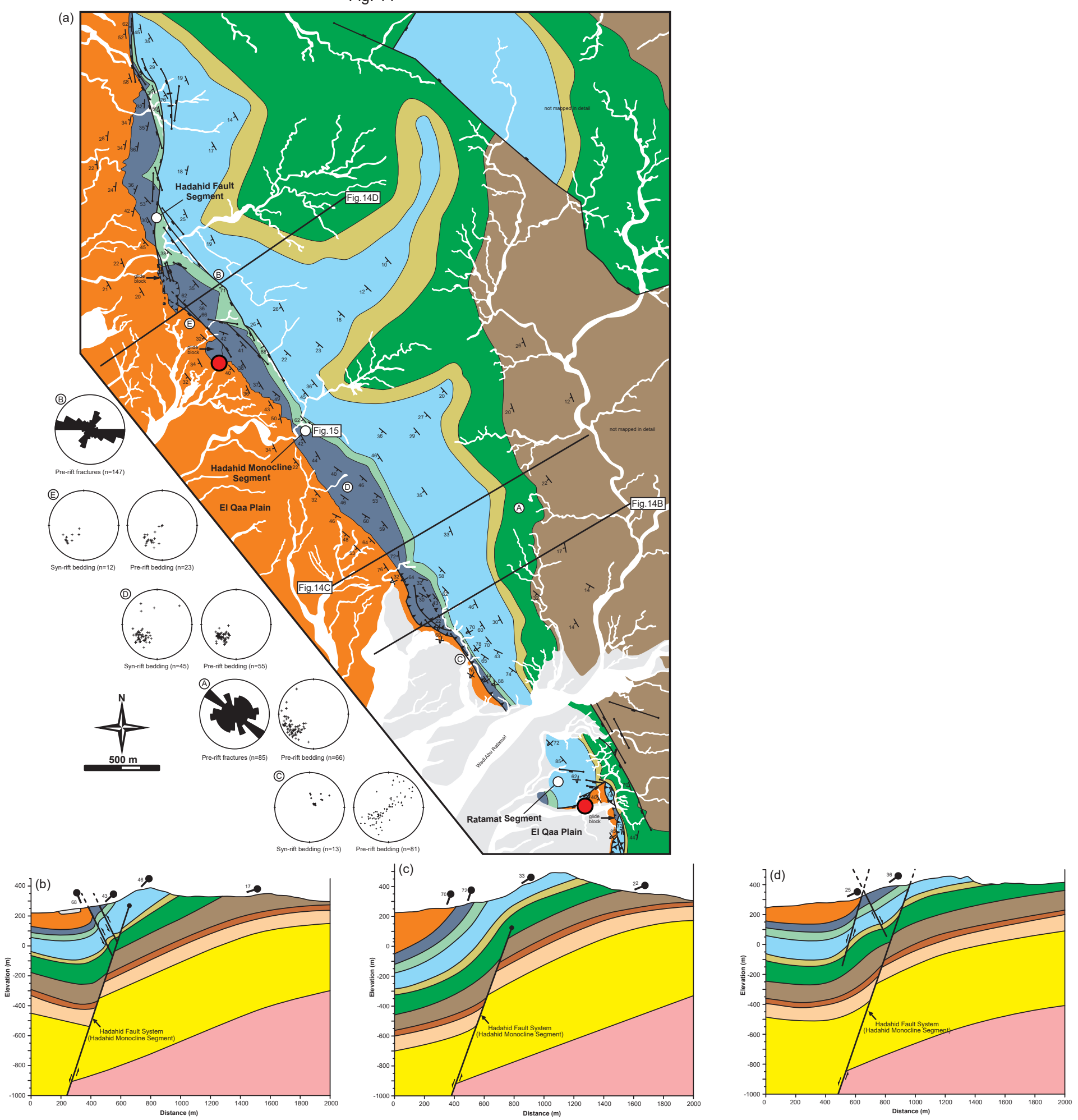
Fig.15

W

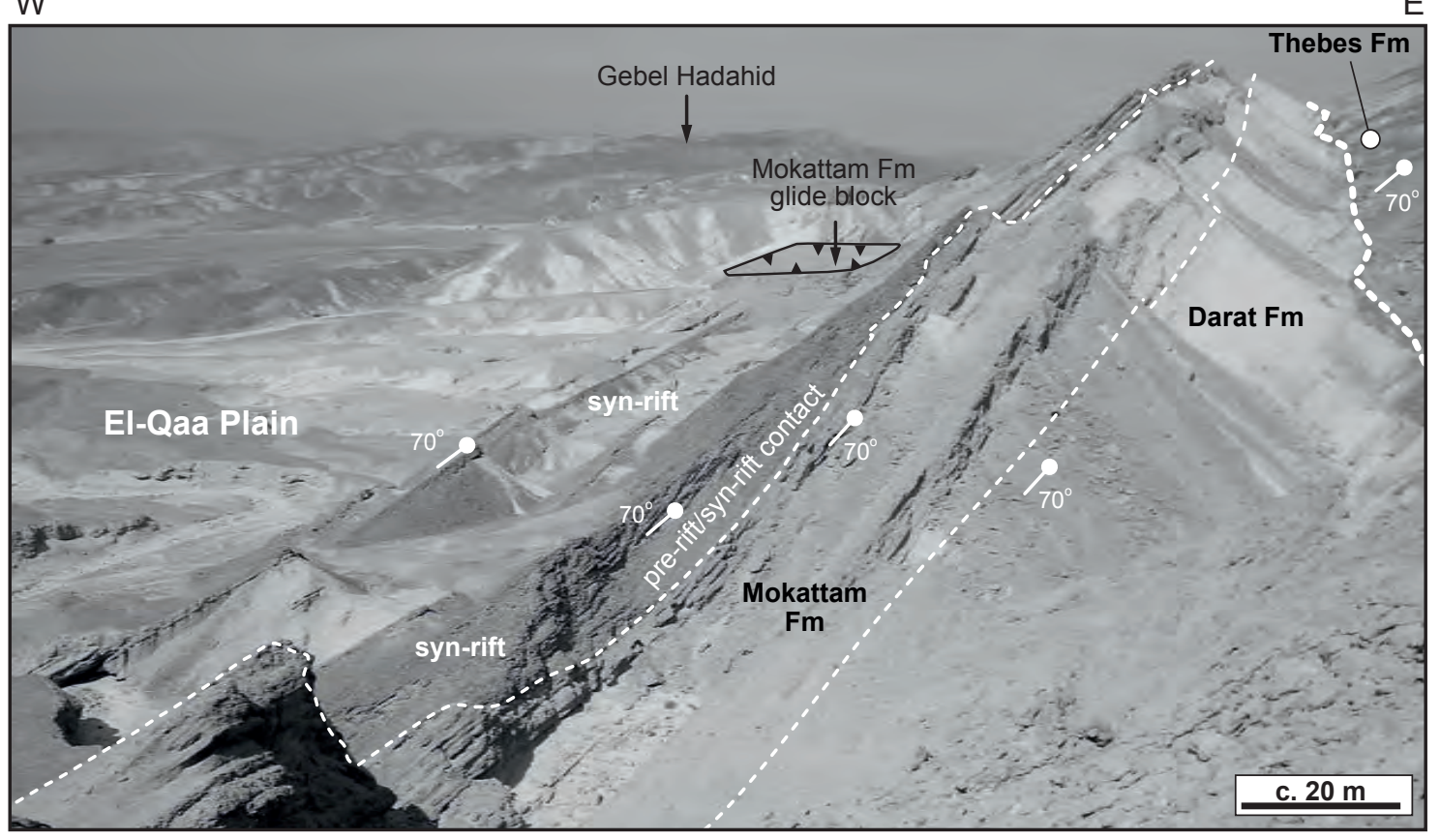


Fig.16

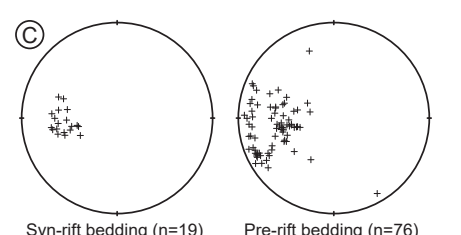

(a)
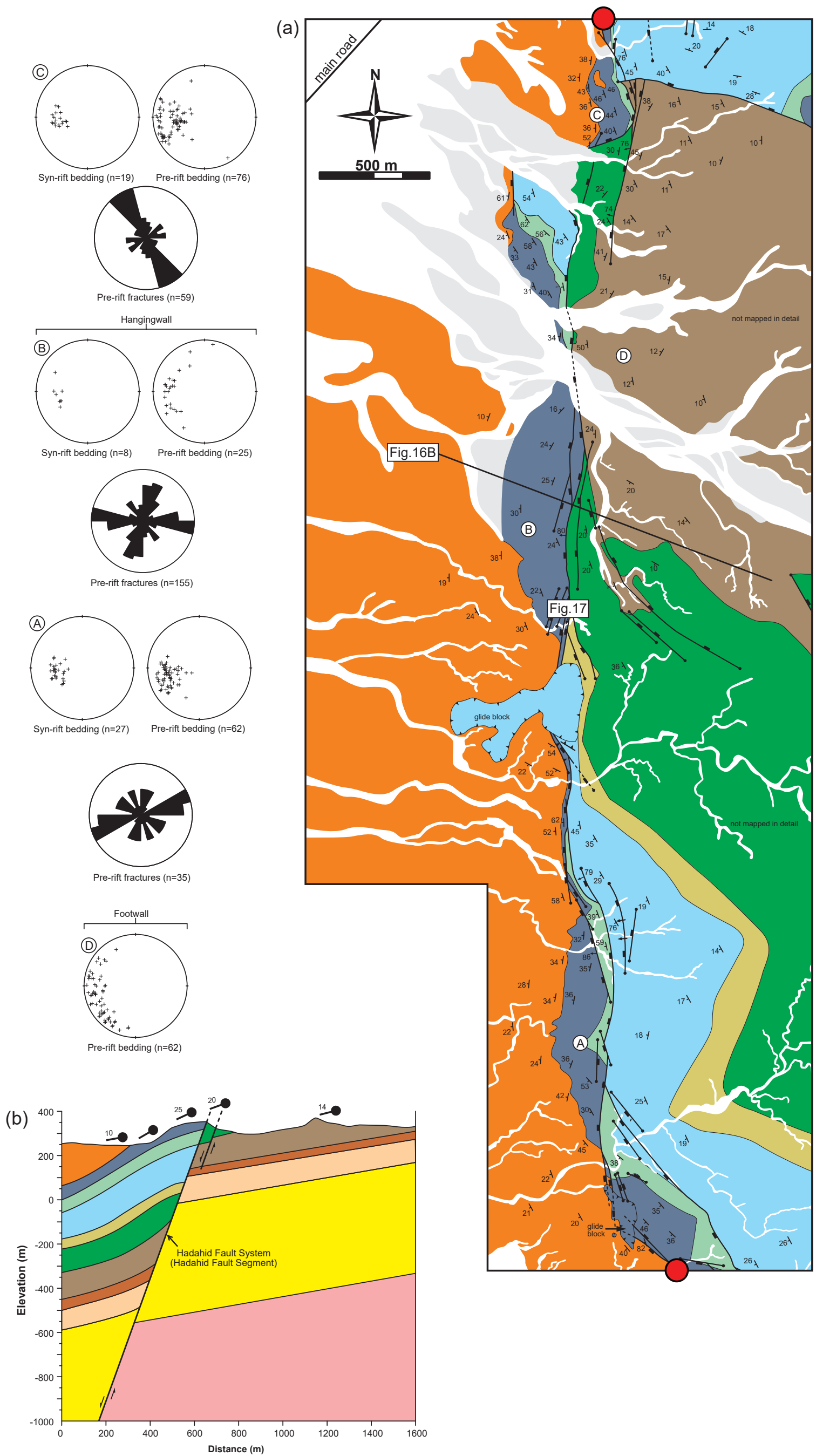
Fig. 17

S

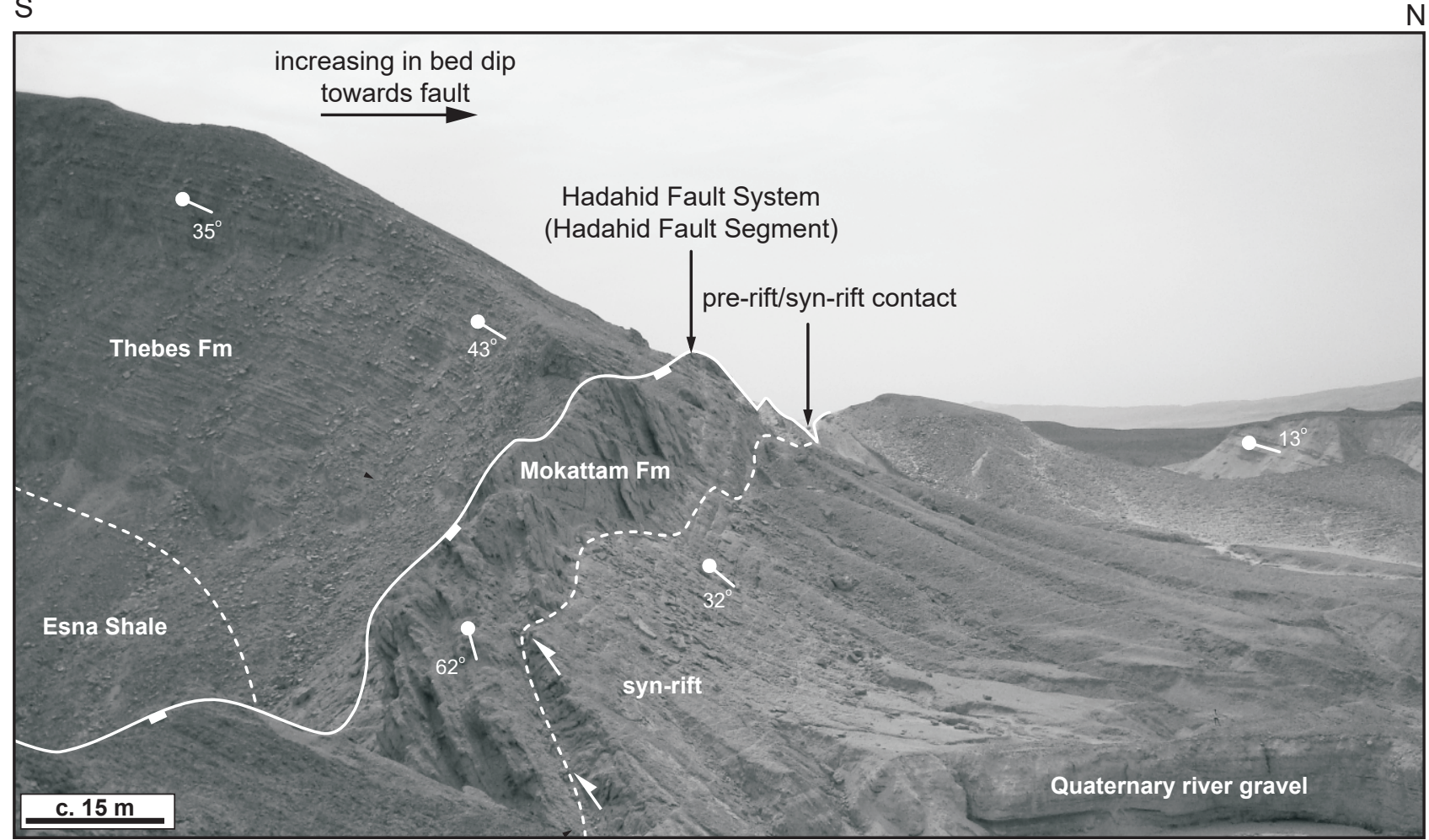


Fig.18
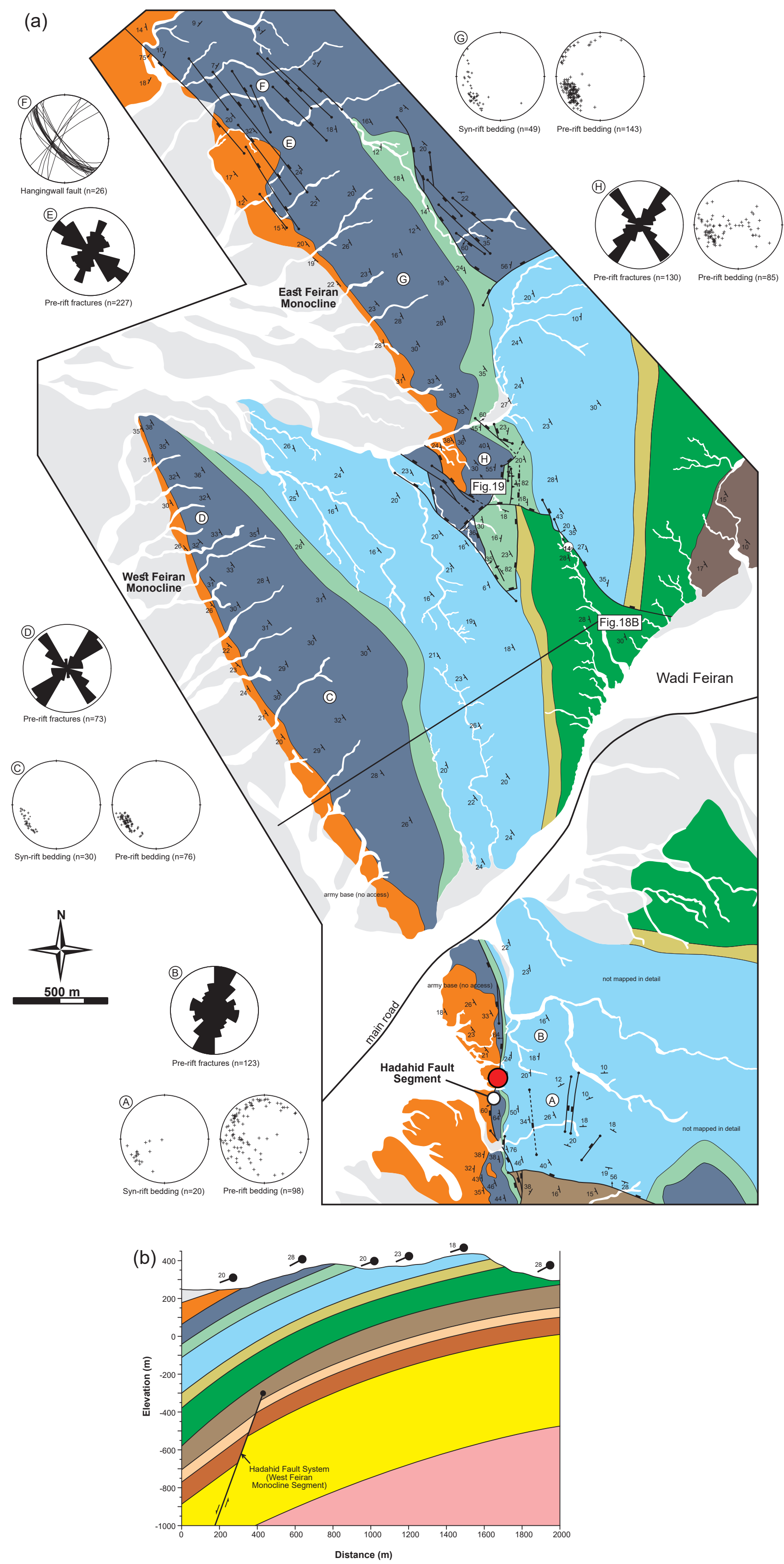
Fig.19

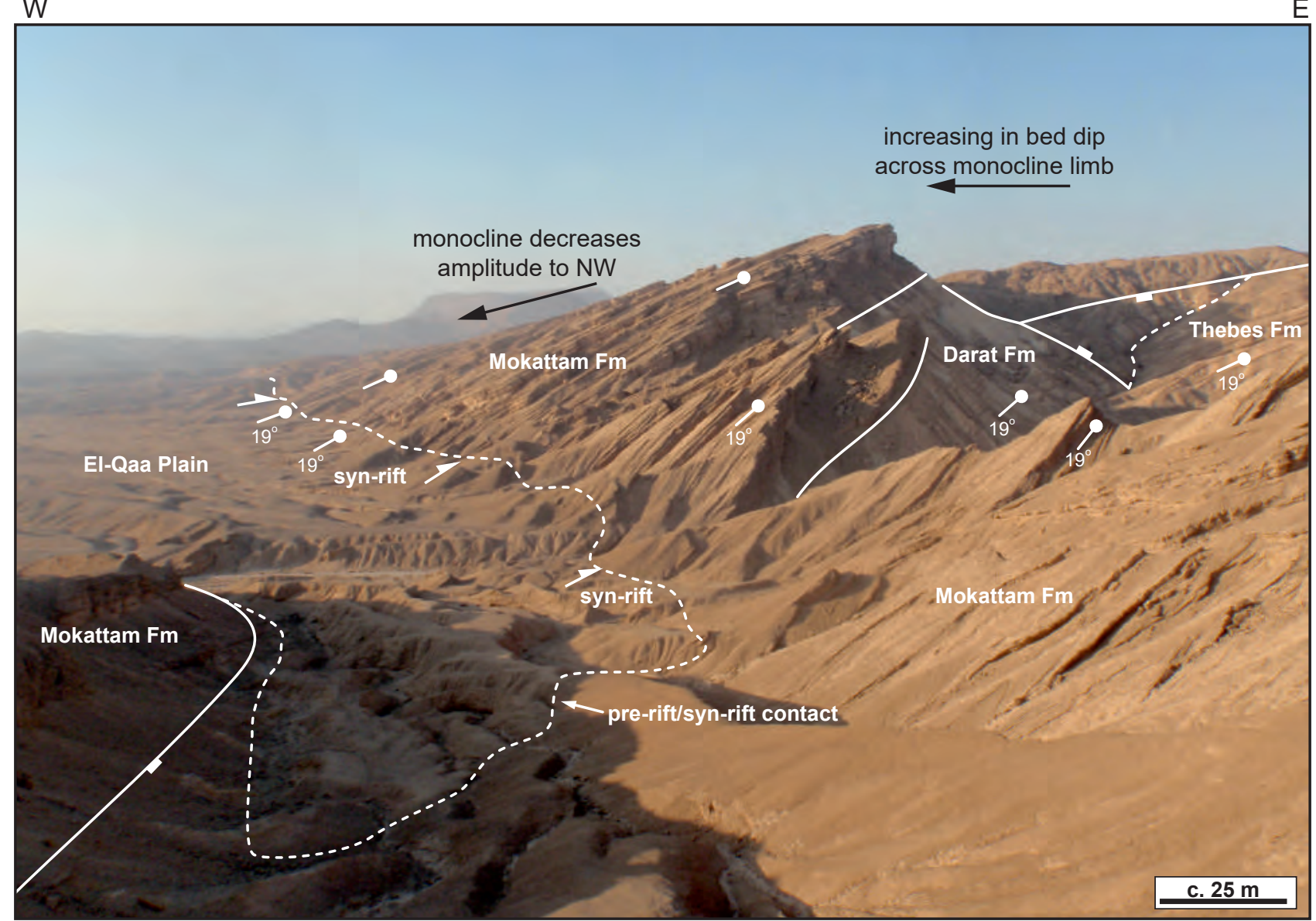




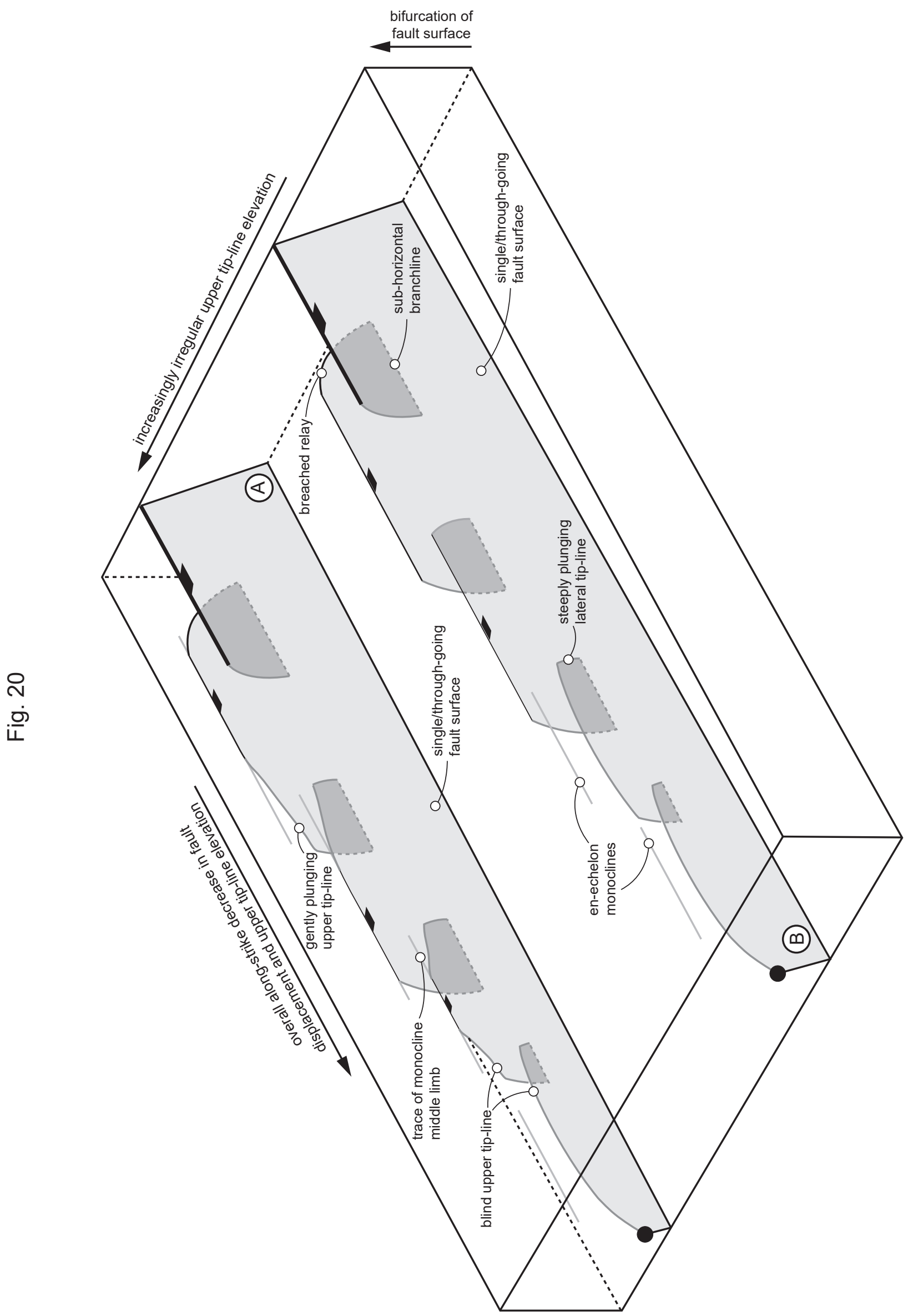

